\title{
Production and enzymatic hydrolysis of carbohydrates in intertidal sediment
}

\author{
Daniel C. O. Thornton ${ }^{1, *}$, Sarah M. Kopac ${ }^{2,3}$, Richard A. Long ${ }^{3,4}$ \\ ${ }^{1}$ Department of Oceanography, Eller O \& M Building, Texas A\&M University, College Station, Texas 77843-3146, USA \\ ${ }^{2}$ Department of Biology, Wesleyan University, Middletown, Connecticut 06459, USA \\ ${ }^{3}$ Department of Biological Sciences and ${ }^{4}$ Marine Science Program, University of South Carolina, Columbia, \\ South Carolina 29208, USA
}

\begin{abstract}
A significant proportion of microphytobenthos (MPB) production is in the form of intraand extracellular carbohydrates. We measured changes in MPB biomass, associated carbohydrates, and relative exoenzyme activity in an intertidal biofilm over the course of daylight tidal emersion. Two experiments were carried out in North Inlet (South Carolina, USA) during June 2007. MPB biomass accumulated in the upper $5 \mathrm{~mm}$ of sediment during daylight emersion, and there was a loss of biomass after tidal flooding of the sediment, with a $50 \pm 21 \%$ (mean $\pm \mathrm{SD}$ ) decrease in sediment chl a content. Six carbohydrate fractions were measured in the sediment, and there were significant positive correlations between chl $a$ and all carbohydrate fractions, indicating that the MPB was the major source of carbohydrates in the sediment, despite significant local primary production by Spartina alterniflora. Rates of relative glycosidase activity followed the pattern: $\beta$-glucosidase $>\alpha$-glucosidase $>(\beta$-xylosidase $=\beta$-galactosidase $=\alpha$-galactosidase $)$. Glucosidase enzymes dominated the hydrolysis of carbohydrates, contributing $70 \pm 6 \%$ of the measured total relative exoenzyme activity. There were significant positive correlations between the total and hot water-extracted carbohydrates in the sediment with relative $\alpha$-glucosidase activity. Relative $\alpha$-galactosidase activity was positively correlated with the saline-extractable and saline-extractable low molecular weight fractions. In addition to $\beta$ glucosidase, other exoenzymes play a significant role in the remineralization of exopolymers in MPBdominated intertidal sediments.
\end{abstract}

KEY WORDS: Acidic polysaccharides $\cdot$ Exoenzyme $\cdot$ Exopolymers $\cdot$ EPS $\cdot$ Glucosidase $\cdot$ Glycosides Microphytobenthos $\cdot$ North Inlet

\section{INTRODUCTION}

The microphytobenthos (MPB) of intertidal sediments is usually dominated by pennate diatoms and Cyanobacteria (Stal 2003, Underwood \& Paterson 2003). MPB makes a substantial contribution to the autotrophic biomass, primary productivity, and biogeochemistry of estuaries (Underwood \& Kromkamp 1999). Annual productivity on temperate intertidal mudflats is in the range of $10 \mathrm{~s}$ to $100 \mathrm{~s} \mathrm{~g} \mathrm{C} \mathrm{m} \mathrm{g}^{-1}$ (Thornton et al. 2002). This productivity is supported by a MPB biomass in the range of $10 \mathrm{~s}$ to $100 \mathrm{~s} \mathrm{mg} \mathrm{m}^{-2}$ as chl a (De Jonge \& Colijn 1994, Santos et al. 1997, Thornton et al. 2002). While most research has focused on temperate ecosystems in Europe and North America, recent work has shown that the MPB is also a significant primary producer in subtropical ecosystems (Thornton \& Visser 2009), tropical ecosystems (Werner et al. 2008), and the Arctic (Glud et al. 2002).

Carbohydrates play an important role in the ecology of benthic diatoms. Carbon fixed by photosynthesis is stored within the cells in the form of glucan, a polymer of glucose (Bellinger et al. 2005, Abdullahi et al. 2006). A significant proportion of the carbon fixed by diatomdominated MPB is exuded into the surrounding environment as carbohydrates (Smith \& Underwood 1998, de Brouwer et al. 2002, Bellinger et al. 2005). These carbohydrates are in the form of both low molecular 
weight (LMW; e.g. simple sugars) and high molecular weight (HMW; e.g. polysaccharides) material. Polysaccharides form extracellular polymeric substances, also known as exopolymers. Both of these interchangeable terms are abbreviated to EPS. The allocation of photosynthetically fixed carbon to the production of extracellular carbohydrates ranges from 1.7 to $73 \%$, of which 0.05 to $20 \%$ is in the form of EPS (Underwood \& Paterson 2003). EPS production rates by the MPB in sediments range from 0 to $18.2 \mu \mathrm{g}$ glucose equivalents ( $\mu$ g chl $a)^{-1} \mathrm{~h}^{-1}$, or up to $1000 \mu \mathrm{g} \mathrm{C} \mathrm{m}^{-2} \mathrm{~h}^{-1}$ (reviewed by Underwood \& Paterson 2003). Epipelic diatoms produce EPS to affect their movement through the sediment, including vertical migrations in response to light and tidal status (Sêrodio et al. 1997). EPS create a complex microhabitat at the sediment surface and affect biostabilization (Holland et al. 1974, Tolhurst et al. 2006). EPS form a large pool of organic carbon in the ocean; Verdugo et al. (2004) estimated that there is $70 \mathrm{Pg}$ of carbon as EPS, compared 1 to $2 \mathrm{Pg} \mathrm{C}$ in the form of living organisms (Falkowski et al. 2000).

Pulse-chase experiments with ${ }^{14} \mathrm{C}$ have shown that glucan is the precursor for EPS (Smith \& Underwood 1998, Underwood et al. 2004) and colloidal carbohydrates (Underwood et al. 2004). Colloidal carbohydrate is often used to describe the soluble (in saline or EDTA solutions) fraction of extracellular carbohydrates that are recovered from sediments and cultures of benthic diatoms (Underwood et al. 1995, 2004, Staats et al. 1999, 2000). However, this term is misleading, as the soluble extracellular carbohydrate pool is composed of LMW and HMW dissolved carbohydrates, colloidal material (Haynes et al. 2007), and potentially gel particles (Verdugo et al. 2004). The carbohydrates exuded by the MPB are utilized by other organisms in the ecosystem, including bacteria and animals (Underwood \& Paterson 2003). MPB carbon has been traced through grazers, suspension feeders, and carnivores using natural stable isotope abundance (Takai et al. 2004). Pulse-chase experiments with ${ }^{13} \mathrm{C}$ showed that inorganic carbon was rapidly assimilated by intertidal MPB via photosynthesis and transferred to nematodes within $1 \mathrm{~h}$ (Middelburg et al. 2000).

Most recent work on the biogeochemistry of MPB carbohydrates has focused on rates and pathways of production in cultures and natural sediments (Smith \& Underwood 1998, Staats et al. 2000, Underwood et al. 2004). While it is known that carbon fixed by the MPB is assimilated by other organisms, relatively little is known about the processes that affect the transport and remineralization of carbohydrates produced by the MPB. A substantial proportion of the MPB is regularly resuspended in many coastal systems (De Jonge \& Van Beusekom 1992, Guarini et al. 2004) by tidal and winddriven mixing. This observation would imply that extracellular carbohydrates are also resuspended. Discrete sections of MPB biofilm have been observed to be carried with the ebbing tide off intertidal mudflats in North Inlet (the site of this research) in South Carolina (D. Thornton pers. obs.). Hanlon et al. (2006) measured carbohydrate pools in intertidal sediments during emersion periods and subsequent immersion of the sediment. They found that chl $a$, EPS, and colloidal carbohydrates were rapidly lost from the sediment within 30 min of tidal flooding as a result of in situ degradation and 'wash-away' into the overlying water. Moreover, there was an accumulation of glucan and colloidal carbohydrate during daytime illuminated tidal emersion (Hanlon et al. 2006).

Pulse-chase experiments using ${ }^{13} \mathrm{C}$ in natural sediments have shown that sediment bacteria rapidly assimilate carbon fixed by the MPB (Middelburg et al. 2000, Bellinger et al. 2009). Haynes et al. (2007) conducted microcosm experiments in which sediments were enriched with colloidal carbohydrates or EPS and they examined the response of the bacterial community, concluding that taxon- and substrate-specific responses by the bacterial community are important in the degradation of extracellular carbohydrates within the sediment. Extracellular carbohydrates produced by benthic diatoms are accessible to bacteria in comparison with intracellular carbohydrate pools such as glucan. However, extracellular molecules $>600$ Da are generally too big to be taken up by bacterial cells (Weiss et al. 1991, Nagata 2008). This means that polysaccharides (such as EPS) must be hydrolyzed outside of the bacterial cytoplasmic membrane by exoenzymes before the carbon can be transported into the cell and assimilated. Glycosidases are extremely common enzymes that catalyze the hydrolysis of carbohydrates by breaking glycosidic linkages resulting in the formation of 2 smaller sugars. Bacteria produce extracellular glycosidases to enable them to break down polysaccharides into their constituent monosaccharides. Hanlon et al. (2006) showed that reducing sugars were rapidly produced in emersed intertidal sediments, indicating exoenzyme activity. Van Duyl et al. (1999) found that $\beta$-glucosidase activity was coupled to bacterial production in intertidal sediments. Haynes et al. (2007) found significant activity of $\beta$-glucosidase in their microcosms, indicating that this exoenzyme was important in the degradation of diatom-derived carbohydrates and the formation of glucose within the sediment. In addition to glucose, EPS produced by benthic diatoms is dominated by neutral sugars such as mannose, galactose, xylose, and rhamnose (Staats et al. 1999, Underwood et al. 2004). Therefore, it is likely that glycosidases other than $\beta$-glucosidase are important in the dynamics of carbohydrates in intertidal sediments. 
The objective of this work was to determine whether the relative activity of enzymes other than $\beta$-glucosidase is significant in MPB biofilms and whether commonly measured carbohydrate fractions in the sediment can be related to exoenzyme activity. Exoenzyme relative activities ( $\alpha$-glucosidase, $\beta$-glucosidase, $\alpha$ galactosidase, $\beta$-galactosidase, and $\beta$-xylosidase) were determined and carbohydrate content measured in intertidal sediments over the course of a daylight emersion period when the MPB is actively photosynthesizing. Four specific hypotheses were tested:

$H_{1}$ : The relative activity of each exoenzyme is significantly $>\mathbf{0}$. If enzymes in addition to $\beta$-glucosidase are significant in the hydrolysis of intertidal sediment carbohydrates, then it should be possible to measure the activity of these enzymes. Alternatively, if an exoenzyme is not significant, then there will be no measurable activity. This hypothesis was tested for each of the exoenzymes measured in the sediment.

$\mathrm{H}_{2}$ : There is a significant change in relative exoenzyme activity over the course of the tidal emersion period. There are significant changes in the mudflat environment over the course of the emersion period. These changes may be physical, such as de-watering (Perkins et al. 2003) and temperature changes (Blanchard et al. 1996). They may also be biological, such as the accumulation of MPB biomass and carbohydrates at the sediment surface (Van Duyl et al. 1999, Hanlon et al. 2006). It is likely that these changes in the sediment habitat affect exoenzyme activity. Hanlon et al. (2006) found significant changes in the rate of reducing sugar production over the course of the emersion period, which suggests changes in the rate of glycosidase activity. This hypothesis was tested for each of the exoenzymes measured.

$\mathrm{H}_{3}$ : Relative exoenzyme activity positively correlates with the sediment content of EPS. EPS are complex carbohydrates that cannot be utilized by bacteria without hydrolysis into smaller subunits (monosaccharides to trisaccharides, Arnosti 2004). There may be a positive correlation between the availability of substrate and relative exoenzyme activity.

$\mathrm{H}_{4}$ : Relative exoenzyme activity is negatively correlated with the sediment content of LMW carbohydrates. Exoenzymes cost microorganisms both energy and resources to produce. Consequently, their production and activity is tightly regulated (Arnosti 2004). One mechanism that regulates catabolic enzyme activity is negative feedback or end-product inhibition, which is the inhibition of exoenzyme activity when the products of hydrolysis are available to the microorganism. When LMW carbohydrates are available, the investment of resources into costly enzymes makes little sense. Van Duyl et al. (1999) proposed that endproduct inhibition explained the relatively low observed rates of hydrolysis in the surface of MPBdominated intertidal sediments (0 to $2 \mathrm{~mm}$ ) compared with at depth (10 to $12 \mathrm{~mm}$ ).

\section{MATERIALS AND METHODS}

Field site and in situ sampling. The field site was located in North Inlet in South Carolina (USA), which is in the North Inlet-Winyah Bay National Estuarine Research Reserve (NERR). The sample site was a tidal creek characterized by unvegetated sediments on the creek bed surrounded by vegetated mudflats dominated by smooth cordgrass Spartina alterniflora. The sediments in the creek were cohesive mud (approximately 5 to $10 \mathrm{~mm}$ deep) overlying muddy sand. Expt 1 was conducted on 24 June 2007 (3321.038' N, $\left.79^{\circ} 11.516^{\prime} \mathrm{W}\right)$, and Expt 2 was conducted on 25 June $2007\left(33^{\circ} 21.034^{\prime} \mathrm{N}, 79^{\circ} 11.519^{\prime} \mathrm{W}\right)$, just upstream of Expt 1 . The field sites were located within 5 min walk from the Baruch Marine Field Laboratory, enabling samples to be rapidly transferred to the laboratory. The site on each sampling occasion was a strip of mudflat $0.25 \mathrm{~m}^{2}(0.25 \mathrm{~cm} \times 1 \mathrm{~m})$ running parallel to the creek to ensure that samples were taken at the same height on the shore. Replicate samples were taken with minicores at random from within each site. Expt 2 was a repeat of the first experiment with the objectives of verifying the results of the first experiment and to increase the resolution of sampling within the tidal emersion period. Expt 2 was not considered a continuation of Expt 1, as it was conducted in a different portion of the creek.

Samples were collected at several time points in each experiment during tidal emersion from unvegetated sediments in the creek bed below the Spartina zone. On each sampling occasion, the temperature of the sediment surface was measured using an electronic thermometer. Sediment cores were taken using minicorers constructed from $60 \mathrm{ml}$ syringes. The minicorers were used to collect sediment cores with a surface area of $661 \mathrm{~mm}^{2}$ and a depth of $5 \mathrm{~mm}$. Three minicores were collected to determine the water content of the sediment on each sampling occasion (see below). Five minicores (numbered 1 to 5 ) were collected to determine chlorophyll content, carbohydrate content, and exoenzyme activity on each sampling occasion. Samples from the 5 minicores used for chlorophyll, carbohydrate, and exoenzyme activity were split into 2 paired sub-samples from each minicore. One subsample was used to measure the pigment and carbohydrate content of the sediment. The second sub-sample was used to measure enzyme activity. Therefore, enzyme activity was paired to measurements of sediment carbohydrate and pigment content in each repli- 
cate minicore. Both sub-samples were immediately returned to the laboratory. Sub-samples for carbohydrate and pigment analysis were immediately frozen at $-80^{\circ} \mathrm{C}$ and then transferred to $-20^{\circ} \mathrm{C}$ until they were lyophilized. The remainders of minicores 1 to 3 were immediately used to measure relative exoenzyme activity. The remaining sediment from minicores 4 and 5 was discarded, as it was logistically not possible to measure exoenzyme activity in more than 3 replicates.

Sediment water content. Each minicore was placed in a pre-weighed scintillation vial, and the wet weight of the sediment was determined. The sediment was dried at $85^{\circ} \mathrm{C}$ and re-weighed. The water content of the sediment was determined from the difference between wet and dry weights.

Laboratory preparation of the sediment. The sediment cores for carbohydrate and pigment analysis were lyophilized for $24 \mathrm{~h}$ in the dark to remove water. The dried sediments were crushed and mixed with a mortar and pestle. Macroscopic plant fragments were picked from the sediment samples with forceps. The lyophilized sediments were placed in scintillation vials and stored at $-20^{\circ} \mathrm{C}$ in the dark in bags containing silica gel desiccant.

Pigment analysis. A sub-sample of sediment from each core $(\sim 100 \mathrm{mg})$ was weighed into a $15 \mathrm{ml}$ centrifuge tube. Pigments were extracted with $2 \mathrm{ml}$ icecold methanol saturated with $\mathrm{MgCO}_{3}$. Extractions were carried out over $24 \mathrm{~h}$, during which time the tubes were kept in the dark at $4^{\circ} \mathrm{C}$ and shaken occasionally. The tubes were then centrifuged (Eppendorf centrifuge $5804 \mathrm{R})$ at $3000 \times g(15 \mathrm{~min})$ and a temperature of $4^{\circ} \mathrm{C}$. Chl a concentrations were estimated spectrophotometrically (Shimadzu 1240 UV-mini spectrophotometer) in $1 \mathrm{ml}$ of extract, using a $1 \mathrm{~cm}$ path semi-micro cuvette, at wavelengths of 665 and $750 \mathrm{~nm}$ before and after acidification with 1 drop of $10 \% \mathrm{HCl}$. Chl a concentrations were calculated according to Stal et al. (1984). Chl a concentrations in the extractions were converted to chlorophyll content in the sediment ( $\mu \mathrm{g} \mathrm{g}^{-1}$ dry sediment) and chlorophyll concentration $\left(\mathrm{mg} \mathrm{m}^{-2}\right)$.

Relative enzyme activity. Hydrolytic exoenzymatic activities in sediments were assessed with 4-methylumbelliferone (MUF)-conjugated substrates (Hoppe 1983). Substrates used in this study were 4-MUF- $\alpha-D-$ glucopyranoside (for $\alpha$-glucosidase activity), 4-MUF- $\beta$ D-glucopyranoside (for $\beta$-glucosidase), 4-MUF- $\alpha$-Dgalactopyranoside (for $\alpha$-galactosidase), MUF- $\beta$-Dgalactopyranoside (for $\beta$-galactosidase), and 4 -MUF- $\beta$ D-xylopyranoside (for $\beta$-xylosidase) (Sigma-Aldrich). Hydrolysis rates were calculated with a MUF standard curve. Results were 'relative exoenzyme activity,' rather than 'exoenzyme activity.' Exoenzyme activity implies that the substrate was added at a sufficiently high concentration to saturate the enzymes present and therefore the measured rates represent maximum potential rates of activity (Nagata 2008). We did not conduct experiments to determine whether the substrates were saturating; therefore, our rates represent relative exoenzyme activity with an initial substrate analog concentration of $100 \mu \mathrm{M}$.

Exoenzymatic activity was performed in triplicate with a heat-killed control. One subsection per minicore was used for each enzyme assay and placed into preweighed test tubes and weighed to determine the mass of the sediment used in each assay. In situ creek water was serially filtered through GF/F and $0.2 \mu \mathrm{m}$ filters, and $3 \mathrm{ml}$ aliquots were added to each sample. Samples were then amended with $100 \mu \mathrm{M}$ final MUF-substrate and vortexed into slurries. Next, $1.4 \mathrm{ml}$ sub-samples were transferred to $2 \mathrm{ml}$ microcentrifuge tubes, and the sediment was pelleted by centrifugation $(5000 \times g$ for $1 \mathrm{~min})$. The fluorescence in the supernatant was measured on a Hoefer TKO-100 fluorometer with an excitation of $365 \mathrm{~nm}$ and an emission of $460 \mathrm{~nm}$. The remaining samples were incubated in the dark at room temperature $\left(21^{\circ} \mathrm{C}\right)$ for the shortest duration for which a signal was obtained to minimize de novo synthesis of exoenzymes, which ranged between 10 and 20 min depending on the enzymes, before a second $1.4 \mathrm{ml}$ aliquot was taken for a final measurement. The heatkilled control sample served as a control for both abiotic hydrolysis and any dissolved enzymes in the $0.2 \mu \mathrm{m}$ filtered creek water used for incubation. Relative exoenzyme activity was normalized both to time and wet sediment weight.

Carbohydrate analysis. Carbohydrate fractions were extracted from the sediments and assayed according to widely used methods (Underwood et al. 1995, Smith \& Underwood 1998, Hanlon et al. 2006). Saline extractions were made from 100 to $150 \mathrm{mg}$ sub-samples of sediment, which were placed in $15 \mathrm{ml}$ polyethylene centrifuge tubes with $5 \mathrm{ml}$ of $25 \%$ (w/v) $\mathrm{NaCl}$ solution. The centrifuge tubes were gently shaken on an orbital shaker for $30 \mathrm{~min}$ at room temperature. After centrifuging at $4500 \times g\left(20 \mathrm{~min}, 4^{\circ} \mathrm{C}\right), 0.8 \mathrm{ml}$ of the supernatant was removed and placed in a Pyrex boiling tube. For accuracy, we used the term 'salineextractable' to describe this pool rather than 'colloidal carbohydrates' commonly used in the literature (see 'Introduction'). Carbohydrate concentrations in the extracts were measured using the phenol-sulfuric acid assay (Dubois et al. 1956) and were expressed as glucose equivalents using calibration curves generated with D-glucose as the standard. Phenol $(0.4 \mathrm{ml}$ of $5 \%$ $\mathrm{w} / \mathrm{v}$ ) was added to each sample followed by $2 \mathrm{ml}$ of concentrated sulfuric acid. The acid was added rapidly using a dispenser bottle. The boiling tubes were agitated by hand and allowed to cool for $20 \mathrm{~min}$. Ab- 
sorbance was measured at $485 \mathrm{~nm}$ in a $1 \mathrm{~cm}$ path semimicro cuvette zeroed against an ultra high purity (UHP) water blank.

Saline-extractable EPS (sEPS) were precipitated from the remaining saline extraction by placing $3 \mathrm{ml}$ in $7 \mathrm{ml}$ of cold $\left(-20^{\circ} \mathrm{C}\right)$ reagent alcohol in a $15 \mathrm{ml}$ centrifuge tube overnight. The sEPS precipitate was separated from the alcohol by centrifugation at $4500 \times g$ at a temperature of $4^{\circ} \mathrm{C}$ for $20 \mathrm{~min}$. Alcohol was carefully removed from the tube, which was placed upside down to enable any remaining alcohol to drain out. Finally, the precipitate was dried in an oven for a few minutes at $75^{\circ} \mathrm{C}$. The precipitate was resuspended in $1 \mathrm{ml}$ of UHP water, and $0.8 \mathrm{ml}$ was analyzed for carbohydrates using the phenol-sulfuric acid assay (Dubois et al. 1956), as described above. The saline-extractable fraction contains both sEPS and LMW carbohydrates. Sediment content of saline-extractable LMW carbohydrates (sLMW) was calculated by subtracting sEPS from the saline-extractable pool.

Total carbohydrates were measured by weighing 2 to $5 \mathrm{mg}$ of sediment into a Pyrex boiling tube and adding $0.8 \mathrm{ml}$ of UHP water. Reagents were added to measure carbohydrate concentrations using the phenol-sulfuric acid assay (Dubois et al. 1956). After the reaction had cooled, the mixture was decanted into $15 \mathrm{ml}$ polyethylene centrifuge tubes and centrifuged at $4500 \times g(20 \mathrm{~min})$ at $4^{\circ} \mathrm{C}$ to remove the sediment. Approximately $1 \mathrm{ml}$ was decanted into a semi-micro cuvette, and the absorbance was measured at $485 \mathrm{~nm}$. Total carbohydrate includes both soluble salineextractable carbohydrate and those particulate carbohydrates that are hydrolyzed by the addition of concentrated $\mathrm{H}_{2} \mathrm{SO}_{4}$.

Serial extraction procedures have been developed to extract polysaccharides that are in the form of EPS bound to the surface of MPB cells and as intracellular storage products (Underwood \& Paterson 2003). Hot water (HW) extractions are largely composed of glucan (Bellinger et al. 2005, Abdullahi et al. 2006), and hot bicarbonate (HB) extractions are associated with polymers tightly bound to the cell wall (Abdullahi et al. 2006, Hanlon et al. 2006). These carbohydrate fractions were extracted from a separate sub-sample of sediment. Sediment (100 to $120 \mathrm{mg}$ ) was weighed into $15 \mathrm{ml}$ polyethylene centrifuge tubes and extracted with $4 \mathrm{ml}$ of $25 \%$ o (w/v) $\mathrm{NaCl}$ solution for $30 \mathrm{~min}$ in a water bath at $25^{\circ} \mathrm{C}$ to remove saline-extractable carbohydrates from the sediment. After centrifuging at $3000 \times g\left(20 \mathrm{~min}, 4^{\circ} \mathrm{C}\right)$, the supernatant was discarded. The sediment pellet was resuspended in $4 \mathrm{ml}$ of reagent alcohol at room temperature, and after $5 \mathrm{~min}$ the mixture was centrifuged at $3000 \times g\left(20 \mathrm{~min}, 4^{\circ} \mathrm{C}\right)$. The supernatant was discarded and the pellet was resuspended in a second $4 \mathrm{ml}$ of reagent alcohol, which was also discarded after centrifuging. Reagent alcohol extractions removed fats and pigments from the sediment. HW extractions were made by resuspending the washed sediment pellet in $4 \mathrm{ml}$ of UHP water that was maintained at $95 \pm 2{ }^{\circ} \mathrm{C}$ for $60 \mathrm{~min}$ in a water bath. The extraction was centrifuged at $3000 \times g$ $\left(20 \mathrm{~min}, 4^{\circ} \mathrm{C}\right)$. Two sub-samples of supernatant $(1.2 \mathrm{ml})$ were placed in microcentrifuge tubes and frozen $\left(-20^{\circ} \mathrm{C}\right)$ for subsequent carbohydrate analysis. The remainder of the supernatant was discarded, and the $\mathrm{HB}$ extraction was made by resuspending the sediment pellet in $4 \mathrm{ml}$ of $0.5 \mathrm{M} \mathrm{HaHCO}_{3}$ that was maintained at $95 \pm 2^{\circ} \mathrm{C}$ for $60 \mathrm{~min}$. The extraction was centrifuged at $3000 \times g\left(20 \mathrm{~min}, 4^{\circ} \mathrm{C}\right)$. Two sub-samples of the supernatant $(1.2 \mathrm{ml})$ were placed in microcentrifuge tubes and frozen $\left(-20^{\circ} \mathrm{C}\right)$ for subsequent carbohydrate analysis. Carbohydrate concentrations were measured in the $\mathrm{HB}$ and HW extractions using the phenol-sulfuric acid assay (Dubois et al. 1956). We noticed that the HW extractions were colored. To correct for any artifacts introduced by color in the extractions, sample blanks were measured by adding UHP water (rather than phenol) and sulfuric acid to the sample to dilute the sample in the same way as the samples analyzed by the phenol-sulfuric acid assay. The absence of phenol meant that no colored product was produced on the addition of the acid. The absorbance of the sample blanks at $485 \mathrm{~nm}$ was subtracted from the absorbance of the analyzed samples to correct for any color in the HW and HB extracts.

Acid polysaccharides (APS) are a significant component of EPS (Hung et al. 2003, Santschi et al. 2003). APS are detected using alcian blue, a cationic dye that complexes with the carboxyl $\left(-\mathrm{COO}^{-}\right)$and half-ester sulfate $\left(-\mathrm{OSO}_{3}{ }^{-}\right)$groups in APS, but not neutral sugars (Ramus 1977, Passow \& Alldredge 1995). We used the alcian blue method of Thornton \& Visser (2009) to determine the content of water-extractable APS (wAPS) in the sediment. Freeze-dried sediment (150 mg) was weighed into $15 \mathrm{ml}$ polyethylene centrifuge tubes. APS was extracted from the sediment using $12 \mathrm{ml}$ of UHP water for $1 \mathrm{~h}$ in a water bath at $25^{\circ} \mathrm{C}$. The extract was separated from the sediment by centrifuging at $3000 \times g\left(15 \mathrm{~min}, 4^{\circ} \mathrm{C}\right)$. WAPS were stained by placing $5 \mathrm{ml}$ of supernatant into a glass tube to which $1 \mathrm{ml}$ of alcian blue $(0.02 \%$ [w/v] in $0.06 \%$ [v/v] acetic acid) was added. The $\mathrm{pH}$ of the mixture was adjusted to $\mathrm{pH} 2.5$ by adding 21 drops of acetic acid. The mixture was shaken, left for $5 \mathrm{~min}$, and shaken again. The precipitated, alcian blue-stained wAPS was collected on $0.2 \mu \mathrm{m}$ pore size syringe filter containing a surfactant free cellulose acetate (SFCA) membrane (Nalgene). The last $1 \mathrm{ml}$ of filtrate was collected directly into a $1 \mathrm{~cm}$ path micro-cuvette, and the absorbance was measured at $610 \mathrm{~nm}$ against a UHP 
water blank using a spectrophotometer. The color of the filtrate was inversely proportional to the amount of wAPS in the sample. The absorbance of $1 \mathrm{ml}$ of supernatant from the extraction was measured at $610 \mathrm{~nm}$ as a blank to check that there was no significant turbidity or color in the wAPS extract. The assay was calibrated using gum xanthan in UHP water, and the results were expressed as gum xanthan equivalents. Note that all carbohydrate data were normalized to the weight of lyophilized sediments, whereas relative exoenzyme activity was normalized to the wet weight of the sediment.

NERR monitoring data. Water quality and meteorological data were collected at the Oyster Landing monitoring station operated by North Inlet-Winyah Bay NERR. The monitoring station was located on the end of a pier $\left(33^{\circ} 20.977^{\prime} \mathrm{N}, 79^{\circ} 11.331^{\prime} \mathrm{W}\right)$ close to the sampling sites. Data from the Oyster Landing site were downloaded from the Centralized Data Management Office (CDMO) of the Baruch Marine Field Lab, University of South Carolina (http://cdmo.baruch.sc.edu).

Data analysis. Data were analyzed using SigmaPlot 11.0 and SYSTAT 12 (Systat Software). One-tailed $t$-tests were used to determine whether enzyme activity was significantly $>0$ to test $H_{1} . H_{0}$ was $\mu=0$, and the alternative hypothesis was $\mu>0$, where $\mu$ is the mean enzyme activity. This hypothesis was tested separately for each experiment and for each enzyme. One-way analysis of variance (ANOVA) was used to determine whether there was a significant difference in enzyme activity over time $\left(\mathrm{H}_{2}\right)$ during the course of each experiment for each enzyme, and also for total enzyme activity. Total enzyme activity was the sum of the individual enzyme activities. Time was a random factor in this analysis (Underwood 1997). ANOVA was conducted on data that met the assumptions of normality and equality of variance. Data that did not meet these assumptions were $\log (x+1)$ transformed before analysis, or a non-parametric ANOVA was carried out on ranks (Kruskal-Wallis ANOVA). In analyses with fixed factors, pairwise comparisons were made using post hoc tests. Dunn's pairwise comparison was used for datasets in which there were missing data, and the Holm-Sidak or Tukey method was used to make pairwise comparisons in data where group sizes were equal. Correlation analysis was conducted to test $H_{3}$ and $H_{4}$ using the Pearson product moment correlation.

\section{RESULTS}

\section{Environmental characteristics}

Sediment temperature during Expt 1 on 24 June 2007 was $33.7^{\circ} \mathrm{C}$ at $10: 45 \mathrm{~h}$, increasing to $36.5^{\circ} \mathrm{C}$ by
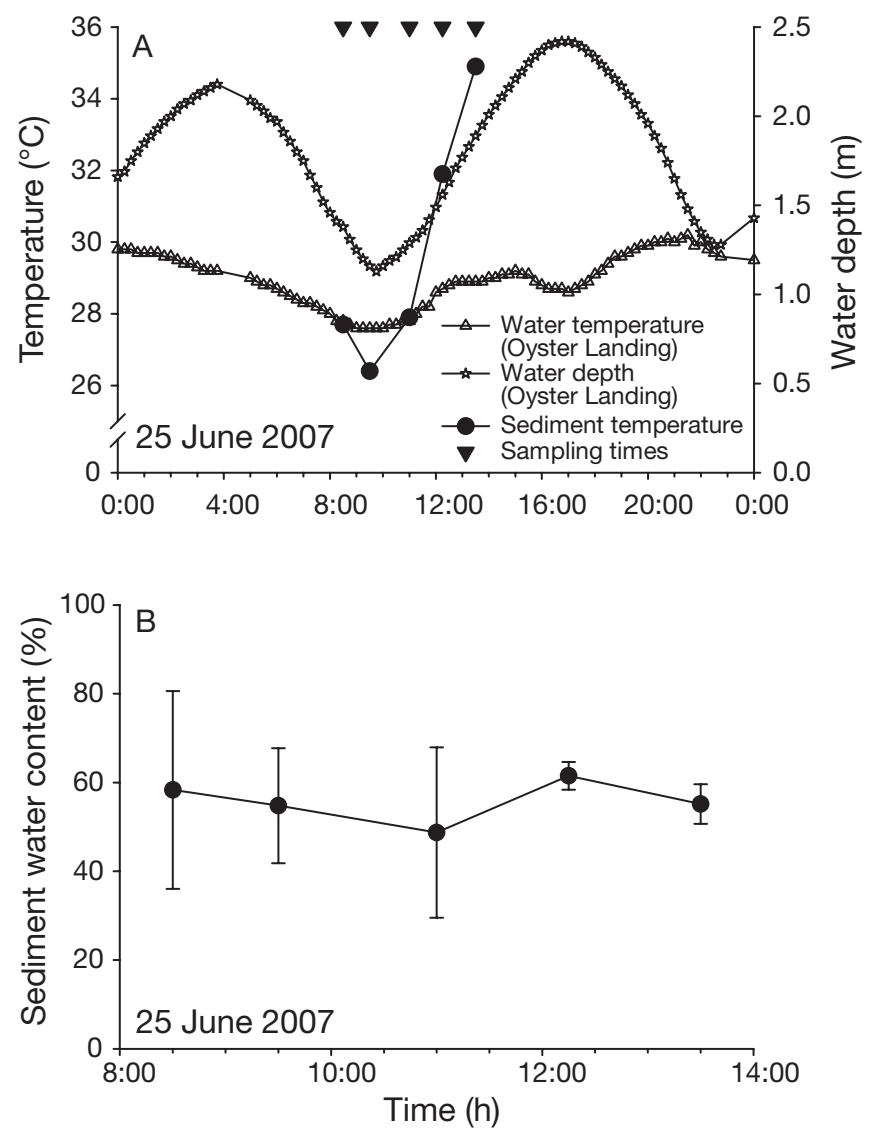

Fig. 1. Changes in the physical environment over tidal emersion during Expt 2. (A) Tidal height and in situ water temperature measured at the Oyster Landing monitoring station. Sediment temperature and sampling times for Expt 2. (B) Sediment water content during Expt 2. Data points show mean \pm $\mathrm{SD}(\mathrm{n}=3)$. The sediments at the sampling stations were located approximately $1.75 \mathrm{~m}$ above the creek bed at the Oyster Landing monitoring station and were exposed to tidal immersion and emersion (see Fig. 2B)

12:30 $\mathrm{h}$. There was no significant change in water content during this time, with a mean water content of 66 and $68 \%$ (by weight) at 10:45 and $12: 30 \mathrm{~h}$, respectively. Water temperature measured at the Oyster Landing monitoring station was lower than the emersed sediment at the Expt 1 site, ranging from a daily minimum of $27.4^{\circ} \mathrm{C}$ at $07: 15 \mathrm{~h}$ to a maximum of $30.7^{\circ} \mathrm{C}$ at $20: 45 \mathrm{~h}$.

Fig. 1 shows changes in the physical environment during Expt 2 on 25 June 2007. The tidal range was $>1 \mathrm{~m}$ (1.13 to $2.42 \mathrm{~m}$ ) at the Oyster Landing monitoring station (Fig. 1A). Water temperature varied from $27.6^{\circ} \mathrm{C}$ between $09: 00$ and $10: 00 \mathrm{~h}$, to $30.2^{\circ} \mathrm{C}$ at $21: 30 \mathrm{~h}$ (Fig. 1A). There was a greater range in sediment temperature during the emersion period of Expt 2, from $26.4^{\circ} \mathrm{C}$ to $34.9^{\circ} \mathrm{C}$ as the sediment flooded. There was no significant change in the water content of the sedi- 
ment during tidal emersion (Fig. 1B), with a mean water content of $56 \pm 13 \%$ (mean $\pm \mathrm{SD}$ ) by weight. Emersion time co-varied with temperature, as both experiments were started in the morning and ended during the middle of the day; therefore, the intense solar radiation received by the sediment warmed it up over the course of the morning.

\section{MPB biomass}

Microscopic examination of fresh surface sediments from both Expts 1 and 2 qualitatively showed that the MPB was dominated by epipelic diatoms from the genera Navicula, Nitzschia, and Cylindrotheca. Fig. 2 shows the change in MPB biomass (as chl a) within the surface $5 \mathrm{~mm}$ of sediment for both Expts 1 and 2. There was an increase in sediment chl a from $32.5 \pm 11.2 \mu \mathrm{g}$ $\mathrm{g}^{-1}$ to $58.6 \pm 25.4 \mu \mathrm{g} \mathrm{g}^{-1}$ during Expt 1 (mean $\pm \mathrm{SD}$ ) (Fig. 2A). These values were equivalent to areal chl $a$ concentrations of $66 \pm 34 \mathrm{mg} \mathrm{m}^{-2}$ and $130 \pm 29 \mathrm{mg} \mathrm{m}^{-2}$, respectively. Maximum chl a content during Expt 2 occurred at the last sampling time before the site was flooded by the tide $\left(41.1 \pm 15.4 \mu \mathrm{g} \mathrm{g}^{-1}\right)$, and the lowest

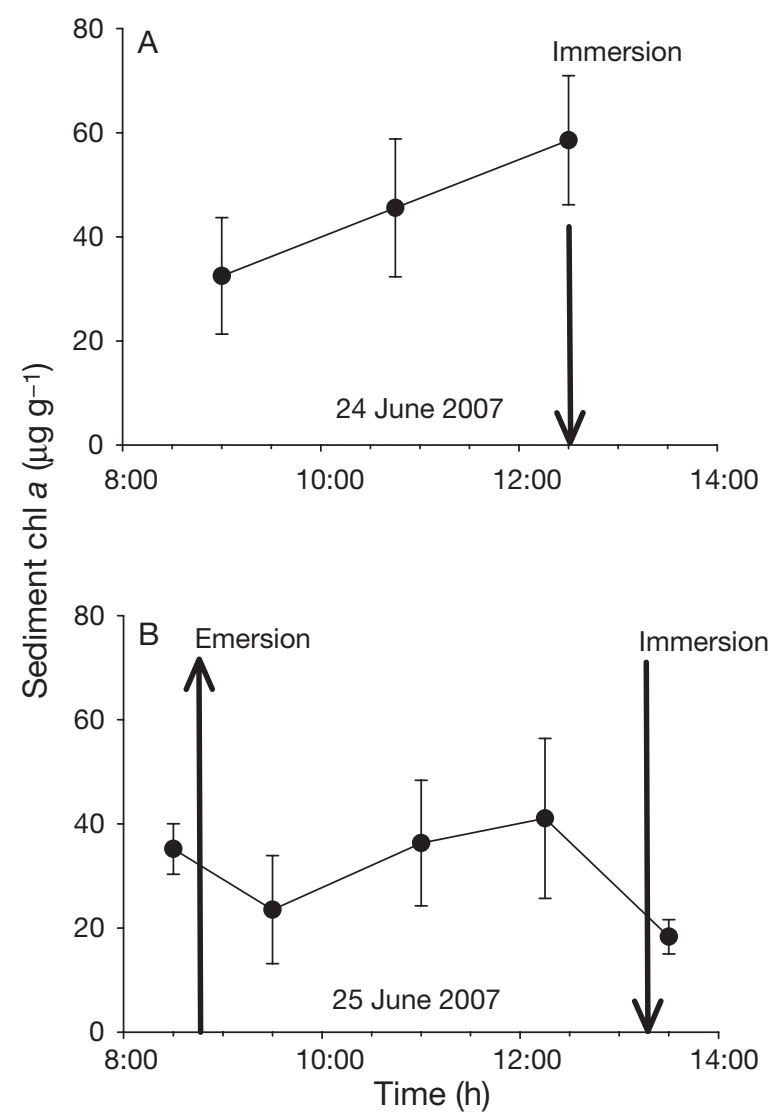

Fig. 2. Mean \pm SD sediment chl a content (dry sediment) during tidal emersion $(n=5)$. (A) Expt 1. (B) Expt 2 sediment chl $a$ occurred at the sampling time immediately after flooding $\left(18.3 \pm 3.3 \mu \mathrm{g} \mathrm{g}^{-1}\right.$; Fig. 2B). These values were equivalent to areal $\mathrm{chl} a$ concentrations of $73 \pm 34 \mathrm{mg} \mathrm{m}^{-2}$ and $43 \pm 15 \mathrm{mg} \mathrm{m}^{-2}$, respectively. There was a significant difference (1-way ANOVA with time as a random factor: $F_{4,20}=4.34, \mathrm{p}<0.05$ ) between sediment chl a content over the whole time course of Expt 2, which started and ended with immersed sediments. Sediment chl a content decreased from 12:15 to 13:30 by $50 \pm 21 \%$ (mean $\pm \mathrm{SD}, \mathrm{n}=5)$. These samples were the last samples, taken before the sediment was flooded (12:15 h) and immediately after flooding by the incoming tide $(13: 30 \mathrm{~h})$. When just the samples taken during tidal emersion were considered, there was a significant positive correlation $(\mathrm{r}=0.533, \mathrm{p}<0.05, \mathrm{n}=$ 15) between chl a content of the sediment and time since emersion during Expt 2.

\section{Relative exoenzyme activity}

Relative exoenzyme activity was measured for all enzymes tested (Table 1), indicating that glucosidase, galactosidase, and xylosidase were hydrolyzing carbohydrates in the sediment. $H_{1}$ was tested for each enzyme in both experiments using $t$-tests (Table 2), which showed that the mean relative exoenzyme activity for each enzyme was significantly $>0$. The general pattern of relative exoenzyme activity was $\beta$-glucosidase $>\alpha$-glucosidase $>(\beta$-xylosidase $=\beta$-galactosidase $=\alpha$-galactosidase) in both experiments (Table 1). When the data from both experiments were pooled (Fig. 3), $\beta$-glucosidase made up $47 \pm 7 \%$ (mean $\pm \mathrm{SD}$, $\mathrm{n}=24$ ) of the total relative enzyme activity. $\alpha$-glucosidase, $\beta$-xylosidase, $\beta$-galactosidase, $\alpha$-galactosidase made up $22 \pm 7,12 \pm 4,8 \pm 4$, and $11 \pm 5 \%$, respectively. Total relative enzyme activity was generally higher during Expt 1 (Table 1); the range of total relative exoenzyme activity varied between 329 and $864 \mathrm{nmol} \mathrm{g}^{-1} \mathrm{~h}^{-1}$. The range of total relative enzyme activity during Expt 2 was 352 to $612 \mathrm{nmol} \mathrm{g}^{-1} \mathrm{~h}^{-1}$. Mean total relative exoenzyme activity was lowest in both experiments at the time point immediately after tidal emersion, which was at 09:00 h for Expt 1 (404 \pm $\left.83 \mathrm{nmol} \mathrm{g}^{-1} \mathrm{~h}^{-1}\right)$ and at 09:30 h for Expt $2(390 \pm 40 \mathrm{nmol}$ $\mathrm{g}^{-1} \mathrm{~h}^{-1}$; Table 1).

One-way ANOVA with time as the random factor for Expt 1 showed a significant difference in mean relative exoenzyme activity for $\beta$-xylosidase $\left(F_{2,6}=13.267, \mathrm{p}<\right.$ 0.01 ), but not for any of the other exoenzymes measured. One-way ANOVA with time as the random factor for Expt 2 showed a significant difference in mean relative exoenzyme activity for $\alpha$-glucosidase $\left(F_{4,10}=\right.$ 7.404, $\mathrm{p}<0.01)$ and $\beta$-galactosidase $\left(F_{4,10}=28.312, \mathrm{p}<\right.$ 0.001). Therefore, $H_{2}$ was rejected for $\beta$-glucosidase 
Table 1. Relative exoenzyme activity ( $\mathrm{nmol} \mathrm{g}^{-1} \mathrm{~h}^{-1}$ ) during Expts 1 and 2 conducted on 24 and 25 June 2007, respectively. Sediments incubated with $100 \mu \mathrm{M}$ 4-methylumbelliferone-conjugated substrate analogs. Total is the mean sum of the relative activity of all enzymes measured. Values are means $\pm \mathrm{SD}(\mathrm{n}=3)$ in wet sediment

\begin{tabular}{|c|c|c|c|c|c|c|c|c|}
\hline \multirow[t]{2}{*}{ Enzyme } & \multicolumn{8}{|c|}{-Time (h) } \\
\hline & $\begin{array}{c}\text { 09:00 } \\
\text { (Expt 1) }\end{array}$ & $\begin{array}{c}10: 45 \\
\text { (Expt 1) }\end{array}$ & $\begin{array}{c}12: 30 \\
\text { (Expt 1) }\end{array}$ & $\begin{array}{c}08: 30 \\
\text { (Expt 2) }\end{array}$ & $\begin{array}{c}09: 30 \\
(\text { Expt 2) }\end{array}$ & $\begin{array}{c}11: 00 \\
\text { (Expt 2) }\end{array}$ & $\begin{array}{c}12: 15 \\
\text { (Expt 2) }\end{array}$ & $\begin{array}{c}13: 30 \\
\text { (Expt 2) }\end{array}$ \\
\hline$\beta$-glucosidase & $185 \pm 29$ & $277 \pm 80$ & $350 \pm 87$ & $282 \pm 36$ & $222 \pm 32$ & $268 \pm 58$ & $287 \pm 13$ & $230 \pm 83$ \\
\hline$\alpha$-glucosidase & $89 \pm 14$ & $219 \pm 15$ & $206 \pm 79$ & $135 \pm 18$ & $48 \pm 10$ & $134 \pm 15$ & $115 \pm 43$ & $91 \pm 14$ \\
\hline$\beta$-xylosidase & $42 \pm 6$ & $87 \pm 15$ & $69 \pm 10$ & $64 \pm 19$ & $66 \pm 21$ & $84 \pm 18$ & $57 \pm 27$ & $54 \pm 10$ \\
\hline$\beta$-galactosidase & $52 \pm 46$ & $122 \pm 17$ & $57 \pm 32$ & $65 \pm 11$ & $36 \pm 7$ & $40 \pm 11$ & $32 \pm 4$ & $89 \pm 3$ \\
\hline$\alpha$-galactosidase & $35 \pm 12$ & $31 \pm 8$ & $63 \pm 20$ & $25 \pm 7$ & $18 \pm 4$ & $45 \pm 22$ & $85 \pm 50$ & $33 \pm 2$ \\
\hline Total & $404 \pm 83$ & $736 \pm 87$ & $744 \pm 182$ & $571 \pm 48$ & $390 \pm 40$ & $571 \pm 35$ & $577 \pm 33$ & $496 \pm 90$ \\
\hline
\end{tabular}

Table 2. Results of 1-tailed $t$-tests to test the hypothesis $\left(H_{1}\right)$ that the relative activity of each exoenzyme was significantly $>0$. $H_{0}$ was $\mu=0$, and the alternative hypothesis was $\mu>0$, where $\mu$ is the mean relative enzyme activity. Table shows values of the $t$-statistics; all $\mathrm{p}<0.001$. For Expt 1, $t_{0.001(1), 8}=4.501$, and for Expt 2, $t_{0.001(1), 14}=3.787$

\begin{tabular}{|lccccc|}
\hline & $\alpha$-glucosidase & $\beta$-glucosidase & $\alpha$-galactosidase & $\beta$-galactosidase & $\beta$-xylosidase \\
\hline Expt 1 & 6.961 & 8.647 & 9.218 & 6.642 & 5.140 \\
Expt 2 & 10.311 & 19.853 & 12.741 & 4.970 & 8.716 \\
\hline
\end{tabular}

and $\alpha$-galactosidase, as there was no significant difference in enzyme activity over time. The results were mixed for the other enzymes, and therefore it appears that exoenzyme activity may either remain relatively constant or change over time during emersion. Oneway ANOVA with time as the random factor showed a significant difference in total relative exoenzyme activity for both Expt $1\left(F_{2,6}=13.267, \mathrm{p}<0.01\right)$ and

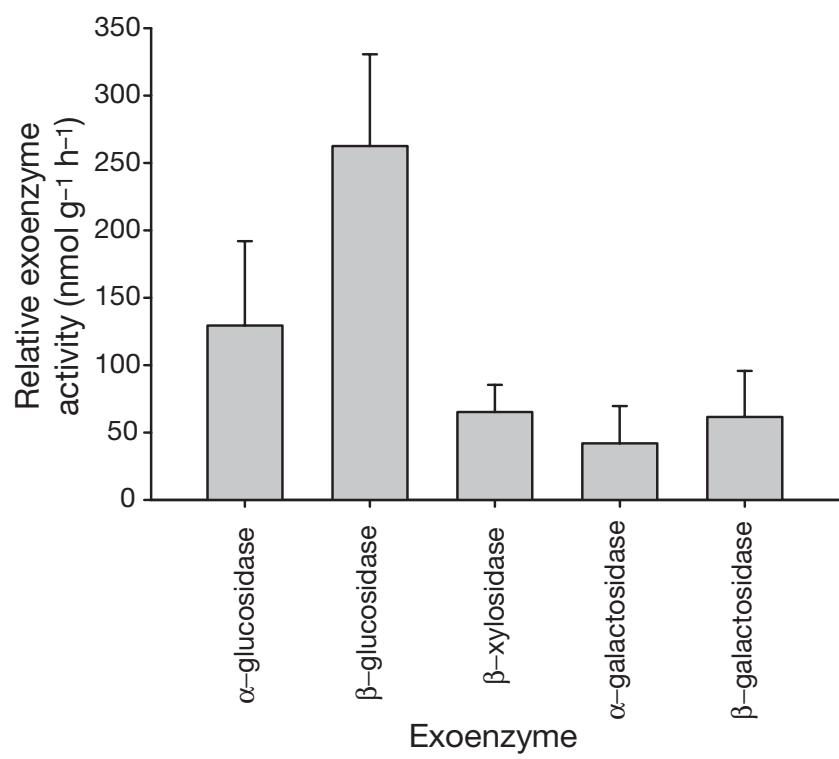

Fig. 3. Mean + SD relative enzyme activity of 5 sediment glycosidases (wet sediment) during tidal emersion. Data were pooled from all sampling occasions from both Expts 1 and $2(\mathrm{n}=24)$
Expt $2\left(F_{4,10}=6.703, \mathrm{p}<0.01\right)$. Consequently, $H_{2}$ was supported for total enzyme activity.

\section{Carbohydrates}

Table 3 shows the mean carbohydrate content of different carbohydrate fractions in the sediment with time in both Expts 1 and 2. Sediment carbohydrate content during Expt 2 was generally lower and more variable than during Expt 1. The total carbohydrate pool was much greater than the sum of the saline-extractable, HW, and HB pools (Table 3 ). This indicated that $>50 \%$ of the carbohydrate was not extracted from the sediment using the extraction methods described above, suggesting that the majority of the total carbohydrate was made up of insoluble carbohydrate. Fig. 4 shows the mean carbohydrate content of the sediment for the data pooled from both Expts 1 and 2. The HW fraction, which is dominated by intracellular carbohydrate storage products, formed the greatest proportion of the total carbohydrate $(18.6 \pm 9.2 \%$; mean \pm SD in dry sediment), whereas sEPS formed the lowest proportion of the total $(1.4 \pm 0.8 \%)$. Mean wAPS concentrations in Expts 1 and 2 were $641 \pm 292 \mu \mathrm{g} \mathrm{g}^{-1}$ and $648 \pm 395 \mu \mathrm{g}$ $\mathrm{g}^{-1}$, respectively, as gum xanthan equivalents $(\mathrm{n}=5)$. There was no significant difference in wAPS concentrations with time in either Expt 1 or 2 . The relative proportions of the different carbohydrate fractions did not change significantly over the course of the emersion period (Table 3 ). 
Table 3. Sediment carbohydrate content $\left(\mu \mathrm{g} \mathrm{g}^{-1}\right.$, except total and HW carbohydrates which are expressed as mg $\left.\mathrm{g}^{-1}\right)$ during Expts 1 and 2 conducted on 24 and 25 June 2007, respectively. HW: hot water; HB: hot bicarbonate; saline: saline-extractable; sEPS: saline-extractable extracellular polymeric substances; sLMW: saline-extractable low molecular weight carbohydrates; wAPS: water-extractable acid polysaccharides. Carbohydrates are expressed as glucose equivalents, with the exception of wAPS, which is in gum xanthan equivalents. SLMW was calculated by subtracting sEPS from saline. Values are means \pm SD $(n=5$; except ${ }^{a}$, where $\mathrm{n}=3$ ) in dry sediment

\begin{tabular}{|c|c|c|c|c|c|c|c|c|}
\hline \multirow{2}{*}{ Carbohydrate } & \multicolumn{8}{|c|}{ Time (h) } \\
\hline & $\begin{array}{c}\text { 09:00 } \\
\text { (Expt 1) }\end{array}$ & $\begin{array}{c}10: 45 \\
(\text { Expt 1) }\end{array}$ & $\begin{array}{c}12: 30 \\
\text { (Expt 1) }\end{array}$ & $\begin{array}{c}08: 30 \\
\text { (Expt 2) }\end{array}$ & $\begin{array}{c}09: 30 \\
\text { (Expt 2) }\end{array}$ & $\begin{array}{c}11: 00 \\
\text { (Expt 2) }\end{array}$ & $\begin{array}{c}12: 15 \\
\text { (Expt 2) }\end{array}$ & $\begin{array}{c}13: 30 \\
\text { (Expt 2) }\end{array}$ \\
\hline Total $\left(\mathrm{mg} \mathrm{g}^{-1}\right)$ & $13.9 \pm 4.6$ & $15.6 \pm 2.6$ & $22.6 \pm 2.9$ & $10.0 \pm 2.6$ & $7.9 \pm 5.3$ & $11.8 \pm 4.9$ & $13.8 \pm 5.6$ & $7.7 \pm 4.7$ \\
\hline Saline & $498 \pm 169$ & $573 \pm 172$ & $764 \pm 160$ & $428 \pm 51$ & $273 \pm 107$ & $483 \pm 162$ & $580 \pm 176$ & $336 \pm 162$ \\
\hline sEPS & $208 \pm 66$ & $215 \pm 57$ & $362 \pm 112$ & $147 \pm 47$ & $76 \pm 44$ & $173 \pm 90$ & $158 \pm 94$ & $54 \pm 50$ \\
\hline sLMW & $290 \pm 109$ & $358 \pm 117$ & $402 \pm 172$ & $281 \pm 33$ & $197 \pm 69$ & $310 \pm 74$ & $422 \pm 97$ & $282 \pm 177$ \\
\hline $\mathrm{HW}\left(\mathrm{mg} \mathrm{g}^{-1}\right)$ & $3.73 \pm 0.81$ & $3.95 \pm 1.29$ & $5.07 \pm 0.71$ & $1.49 \pm 0.52$ & $1.08 \pm 0.79$ & $1.78 \pm 0.78$ & $1.20 \pm 0.95$ & $1.08 \pm 0.58$ \\
\hline HB & $882 \pm 284$ & $833 \pm 372$ & $1190 \pm 281$ & $789 \pm 263$ & $508 \pm 365$ & $836 \pm 378$ & $753 \pm 447$ & $543 \pm 234$ \\
\hline wAPS & $501 \pm 187$ & $624 \pm 330$ & $901 \pm 271^{\mathrm{a}}$ & $810 \pm 496$ & $492 \pm 274$ & $729 \pm 520$ & $569 \pm 223$ & $637 \pm 465$ \\
\hline
\end{tabular}

Table 4. Pearson product moment correlation coefficients (r) between different pools of carbohydrates in intertidal sediment. Data were pooled from Expts 1 and 2 ( $\mathrm{n}=40$, except $\mathrm{n}=38$ for wAPS measurements). ${ }^{*} \mathrm{p}<0.05,{ }^{* *} \mathrm{p}<0.01,{ }^{* * *} \mathrm{p}<0.001$. Correlations where $\mathrm{r}>0.80$ are in bold; abbreviations as in Table 3

\begin{tabular}{|c|c|c|c|c|c|c|c|}
\hline & sEPS & LMW & HW & HB & wAPS & Saline & Chl a \\
\hline Total & $0.778^{* * *}$ & $0.610^{* * *}$ & $0.776^{* * *}$ & $0.770^{* * *}$ & $0.521^{* * *}$ & $0.823^{* * *}$ & $0.829^{* * *}$ \\
\hline sEPS & & $0.400^{*}$ & $0.835^{* * *}$ & $0.789^{* * *}$ & $0.414^{* *}$ & $0.816^{* * *}$ & $0.784^{* * *}$ \\
\hline sLMW & & & $0.447^{* *}$ & $0.588^{* * *}$ & $0.476^{* *}$ & $0.856^{* * *}$ & $0.680^{* * *}$ \\
\hline HW & & & & $0.740^{* * *}$ & $0.348^{*}$ & $0.752^{* * *}$ & $0.871^{* * *}$ \\
\hline HB & & & & & $0.578^{* * *}$ & $0.815^{* * *}$ & $0.768^{* *}$ \\
\hline wAPS & & & & & & $0.511^{* *}$ & $0.456^{* *}$ \\
\hline Saline & & & & & & & $0.871^{* * *}$ \\
\hline
\end{tabular}

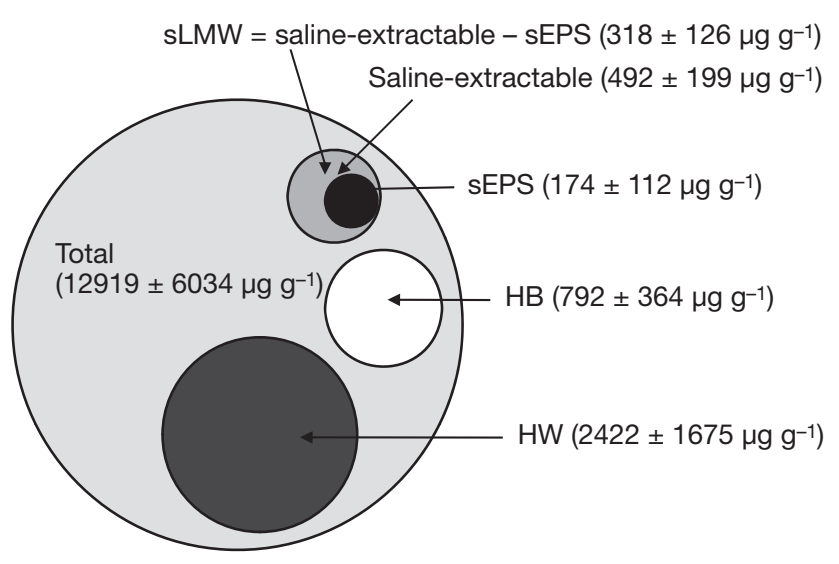

Fig. 4. Relative magnitude and relationships between the 5 carbohydrate pools measured using the phenol-sulfuric acid assay. The area of each circle represents the mean sediment content of that carbohydrate pool. Carbohydrate pools measured were total, hot water (HW), hot bicarbonate (HB), saline-extractable, saline-extractable extracellular polymeric substances (sEPS), and saline-extractable low molecular weight carbohydrates (sLMW). Data were pooled from all sampling occasions from both Expts 1 and 2. Numbers in parentheses are the mean $\pm \mathrm{SD}(\mathrm{n}=40)$ in dry sediment for that carbohydrate pool
There were significant positive correlations between all of the different carbohydrate fractions measured in the sediment (Table 4). Moreover, there were significant positive correlations between MPB biomass (as chl a) and all carbohydrate fractions measured in the sediment (Table 4, Fig. 5). The strongest correlations $(\mathrm{r}>0.80)$ are highlighted in Table 4. MPB biomass was highly correlated with the HW fraction $(\mathrm{r}=0.871)$ and saline-extractable carbohydrates $(\mathrm{r}=0.871)$. There was a significant positive correlation $(\mathrm{r}=0.784$, $\mathrm{p}<0.001$, $\mathrm{n}=15$ ) between emersion time and the sLMW content of the sediment during Expt 2, which indicated that LMW carbohydrates were accumulating in the sediment during daylight emersion. The equivalent analysis was not carried out on Expt 1, as there were only 2 time points during the emersion period. When data from Expts 1 and 2 were pooled together, there was a significant positive correlation $(\mathrm{r}=0.396, \mathrm{p}<0.05, \mathrm{n}=$ 25) between emersion time and the sLMW content of the sediment.

Table 5 shows the correlations between the relative activities of exoenzymes within the sediment, and between exoenzymes and the carbohydrate fractions measured. There were positive correlations between 
the relative exoenzyme activities of $\alpha$-glucosidase and $\beta$-glucosidase, as well as between $\alpha$-glucosidase and $\beta$ galactosidase. Total relative exoenzyme activity was strongly correlated $(\mathrm{r}>0.80)$ with both glucosidases. However, this is not surprising as glucosidases made
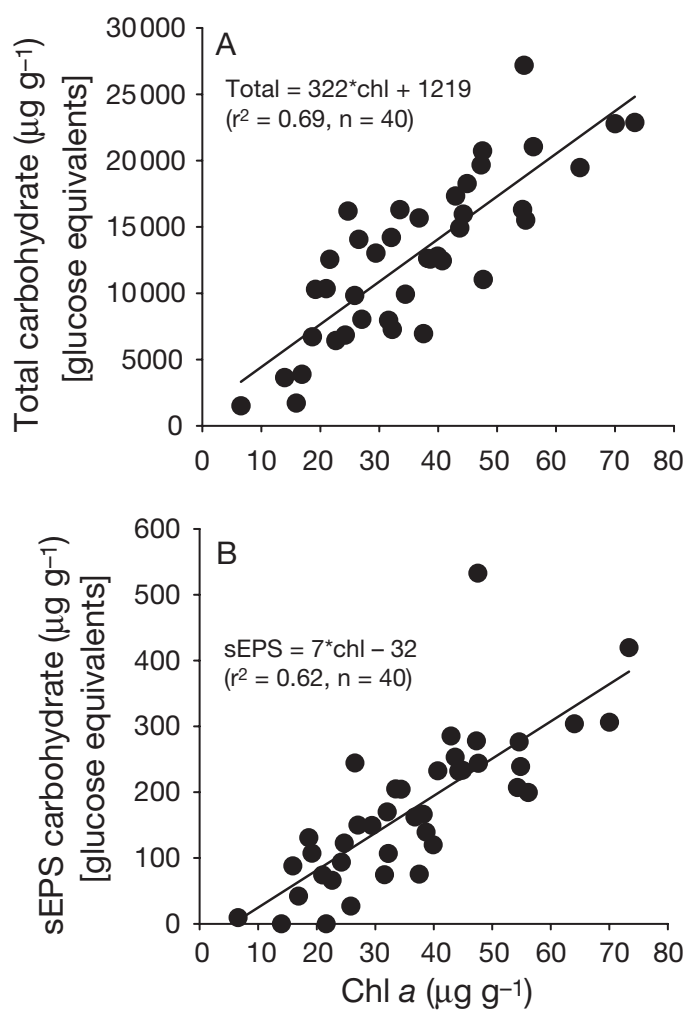

Fig. 5. Relationship between the sediment content of chl $a$ and (A) total carbohydrate, (B) saline-extractable exopolymers (sEPS). Extractions were made from dry sediment the greatest contribution to the total exoenzyme activity. Table 5 shows that $\beta$-glucosidase, $\beta$-xylosidase, $\beta$ galactosidase, and total enzyme activity were not significantly correlated with any of the carbohydrate fractions measured. However, the $2 \alpha$-glycosidases measured did significantly correlate with individual carbohydrate fractions within the sediment. $\alpha$-glucosidase positively correlated with the total and HW fractions, whereas $\alpha$-galactosidase positively correlated with sLMW and the saline-extractable fraction.

\section{DISCUSSION}

\section{Physical environment}

It was expected that the sediment water content would decrease over the course of the emersion period as a result of evaporation and drainage from the sediment. The resulting sediment compaction due to dewatering may result in changes in the concentration of chl $a$ and EPS (Perkins et al. 2003). Dewatering has the biggest effect on sediment close to the sediment-air interface and therefore may not have been significant over the $5 \mathrm{~mm}$ depth sampled in our work. In fact, there was no significant loss of water from the sediments in either Expt 1 or 2. Hanlon et al. (2006) found no significant change in the water content of surface $2 \mathrm{~mm}$ of sediment in the Colne estuary (UK) over an emersion period. Van Duyl et al. (1999) found comparable sediment water content to North Inlet in the Ems-Dollard estuary (Netherlands) during emersion, while observing a significant decrease in water content from a mean of 66.4 to $63.2 \%$ (w/w) during emersion.

Table 5. Carbohydrates and exoenzymes in intertidal sediment. Pearson product moment correlation coefficients (r) between different pools of carbohydrates and relative exoenzyme activity, and between the relative exoenzyme activity of different exoenzymes. Data were pooled from Expts 1 and $2(n=24)$. NS: not significant $(\mathrm{p} \geq 0.05),{ }^{*} \mathrm{p}<0.05,{ }^{* *} \mathrm{p}<0.01,{ }^{* * *} \mathrm{p}<0.001$. Significant correlations are indicated in bold; abbreviations as in Table 3

\begin{tabular}{|c|c|c|c|c|c|c|}
\hline & $\alpha$-glucosidase & $\beta$-glucosidase & $\beta$-xylosidase & $\alpha$-galactosidase & $\beta$-galactosidase & Total enzyme \\
\hline Total carbohydrate & $0.464^{*}$ & $0.170^{\mathrm{NS}}$ & $0.130^{\mathrm{NS}}$ & $0.298^{\mathrm{NS}}$ & $0.062^{\mathrm{NS}}$ & $0.367^{\mathrm{NS}}$ \\
\hline sEPS & $0.355^{\mathrm{NS}}$ & $0.238^{\mathrm{NS}}$ & $0.145^{\mathrm{NS}}$ & $0.310^{\mathrm{NS}}$ & $0.014^{\mathrm{NS}}$ & $0.346^{\mathrm{NS}}$ \\
\hline sLMW & $0.218^{\mathrm{NS}}$ & $0.182^{\mathrm{NS}}$ & $0.009^{\mathrm{NS}}$ & $0.539^{* *}$ & $-0.290^{\mathrm{NS}}$ & $0.214^{\mathrm{NS}}$ \\
\hline HW & $0.450^{*}$ & $0.184^{\mathrm{NS}}$ & $0.156^{\mathrm{NS}}$ & $0.175^{\mathrm{NS}}$ & $0.180^{\mathrm{NS}}$ & $0.375^{\mathrm{NS}}$ \\
\hline $\mathrm{HB}$ & $0.079^{\mathrm{NS}}$ & $0.115^{\mathrm{NS}}$ & $0.231^{\mathrm{NS}}$ & $0.277^{\mathrm{NS}}$ & $-0.003^{\mathrm{NS}}$ & $0.171^{\mathrm{NS}}$ \\
\hline wAPS & $0.031^{\mathrm{NS}}$ & $-0.041^{\mathrm{NS}}$ & $-0.113^{\mathrm{NS}}$ & $0.229^{\mathrm{NS}}$ & $-0.160^{\mathrm{NS}}$ & $-0.015^{\mathrm{NS}}$ \\
\hline Saline & $0.305^{\mathrm{NS}}$ & $0.226^{\mathrm{NS}}$ & $0.076^{\mathrm{NS}}$ & $0.476^{*}$ & $-0.168^{\mathrm{NS}}$ & $0.297^{\mathrm{NS}}$ \\
\hline Chl a & $0.342^{\mathrm{NS}}$ & $0.346^{\mathrm{NS}}$ & $0.167^{\mathrm{NS}}$ & $0.371^{\mathrm{NS}}$ & $-0.0842^{\mathrm{NS}}$ & $0.381^{\mathrm{NS}}$ \\
\hline$\alpha$-glucosidase & - & - & - & - & - & - \\
\hline$\beta$-glucosidase & $0.551^{* *}$ & - & - & - & - & - \\
\hline$\beta$-xylosidase & $0.276^{\mathrm{NS}}$ & $0.163^{\mathrm{NS}}$ & - & - & - & - \\
\hline$\alpha$-galactosidase & $0.131^{\mathrm{NS}}$ & $0.284^{\mathrm{NS}}$ & $0.091^{\mathrm{NS}}$ & - & - & - \\
\hline$\beta$-galactosidase & $0.479^{*}$ & $0.216^{\mathrm{NS}}$ & $0.162^{\mathrm{NS}}$ & $-0.162^{\mathrm{NS}}$ & - & - \\
\hline Total enzyme & $0.860^{* * *}$ & $0.829^{* * *}$ & $0.387^{\mathrm{NS}}$ & $0.352^{\mathrm{NS}}$ & $0.352^{\mathrm{NS}}$ & - \\
\hline
\end{tabular}


The surface of sediments may undergo rapid transitions in temperature between periods of immersion and emersion (Blanchard et al. 1996). At temperate latitudes, air temperatures may be significantly cooler than the water during winter and significantly warmer during summer. The low heat capacity of sediment minerals compared to water means that sediment increases and decreases in temperature much faster than water. Consequently, the surface layers of intertidal sediments are relatively harsh environments in terms of rate of temperature change. During Expt 2, the temperature of the water at Oyster Landing ranged over $1.1^{\circ} \mathrm{C}\left(27.8\right.$ to $\left.28.9^{\circ} \mathrm{C}\right)$ compared to a range of $8.5^{\circ} \mathrm{C}$ in the surface of the sediment $\left(26.4\right.$ to $\left.34.9^{\circ} \mathrm{C}\right)$. Temperature affects physiological processes in MPB biofilms (Blanchard et al. 1996); Hancke \& Glud (2004) found that benthic communities dominated by diatoms became more heterotrophic with increasing temperature. Cylindrotheca closterium is often used as a model benthic diatom in culture experiments; Morris \& Kromkamp (2003) showed that the maximum rate of photosynthesis by C. closterium was sensitive to temperature, and Wolfstein \& Stal (2002) showed that temperature affected EPS production by C. closterium. In an estuary such as North Inlet, where summer temperatures may exceed $40^{\circ} \mathrm{C}$, it is likely that the rapid changes in temperature during emersion affected both the production of carbohydrate by the MPB and processes affecting carbohydrate loss.

\section{MPB biomass}

We measured the MPB biomass in the sediments using chl a as a proxy. Measurements were made using a spectrophotometric method, which shows good agreement with high performance liquid chromatography analysis (Brotas et al. 2007). The biomass of MPB in the upper $5 \mathrm{~mm}$ of sediment was within the range observed for other estuarine systems (Underwood \& Kromkamp 1999, Thornton et al. 2002, Thornton \& Visser 2009). The positive correlation between the chl a content of the sediment and emersion time during Expt 2 indicated that MPB biomass accumulated in surface sediments during emersion. There was a decrease in chl a content of the sediment after immersion during Expt 2. This was probably a result of 'wash-away' of MPB biomass into the overlying water as the sediment was flooded. It is well established that a significant proportion of the phytoplankton in estuarine systems is resuspended MPB (De Jonge \& Van Beusekom 1992, Guarini et al. 2004), and Hanlon et al. (2006) found a significant loss of chl a from the upper $2 \mathrm{~mm}$ of an intertidal sediment within 30 min of flooding. Downward migration into the sediment by the
MPB may have also contributed to the loss of chl a from the upper layer of the sediment. However, we sampled to a depth of $5 \mathrm{~mm}$, and it is unlikely that the small diatoms that dominated the MPB migrated to a depth greater than the sediment cores within $30 \mathrm{~min}$ of immersion. Using the cryolander technique, de Brouwer \& Stal (2001) found that the MPB was concentrated in the upper $0.2 \mathrm{~mm}$ sediment layer during tidal emersion.

\section{Sediment carbohydrates}

Solvent-extractable carbohydrates (sum of salineextractable, HW, and HB fractions) made up 20 to $40 \%$ of the total carbohydrate in the sediment, which is similar to the $50 \%$ observed by Hanlon et al. (2006). Therefore, the majority of the carbohydrates in the sediment were insoluble using these extraction procedures. Much of the carbohydrates in the sediment would have been in the form of insoluble particles. It is likely that fragments of plant material, particularly Spartina alterniflora, contributed to the total carbohydrate pool. While large and obvious plant fragments were removed from the samples prior to analysis, there would have been many microscopic fragments left in the sediment. Carbohydrates tightly bound to sediment grains may not have been removed during solvent extraction. Finally, the total carbohydrate contained the insoluble fraction of the carbohydrate associated with MPB and other organisms in the sediment.

It is probable that the MPB was the major source of the insoluble carbohydrate fraction, as there was a significant correlation $(\mathrm{r}=0.756, \mathrm{p}<0.001, \mathrm{n}=40$ ) between sediment chl $a$ and the insoluble carbohydrates. Moreover, there was a significant linear relationship between $\mathrm{chl} a$ and total carbohydrate (Fig. 5A). Thornton \& Visser (2009) found a significant correlation between chl $a$ and total carbohydrate in the surface $5 \mathrm{~mm}$ of sediments from a subtropical salt marsh in Galveston Bay (Texas, USA). Hanlon et al. (2006) found a significant increase in total carbohydrate during emersion in the Colne estuary. However, other researchers have ignored the total carbohydrate fraction or found a non-significant relationship between total carbohydrate and chl a (Van Duyl et al. 1999, Thornton et al. 2002, Bellinger et al. 2005).

Saline-extractable carbohydrates represented $4.3 \pm$ $2.3 \%$ of the total carbohydrate, which is lower than observed by Bellinger et al. (2005), who found that the mean saline-extractable proportion varied between 11 and $29 \%$. The significant correlation between chl a and saline-extractable carbohydrate indicates that the MPB were the major source of the saline-extractable fraction. Many other researchers have found a signifi- 
cant positive correlation between chl a and salineextractable carbohydrate (Underwood \& Paterson 2003, Bellinger et al. 2005), which was described by a simple model by Smith \& Underwood (1998). The saline-extractable fraction is composed of sEPS and LMW carbohydrates. De Brouwer \& Stal (2001) found that the majority of the saline-extractable carbohydrates produced during daylight emersion were $<10 \mathrm{kDa}$ in size, as determined by ultrafiltration. Alcohol precipitation generally precipitates polymers (i.e. sEPS) >100 kDa (de Brouwer \& Stal 2001). Therefore, defining the remaining carbohydrates as LMW (Bellinger et al. 2005) is relative and is not in keeping with the $<1 \mathrm{kDa}$ definition generally used by organic geochemists to define LMW dissolved organic carbon (DOC; Bianchi 2007). This indicates that much of the 'LMW' fraction of the saline-extractable fraction is not available to bacteria without hydrolysis into smaller subunits. This conclusion was supported by the positive correlation between the sLMW content of the sediment and relative $\alpha$-galactosidase activity in the sediment.

sEPS content of the sediment was $<2 \%$ of the total carbohydrate; therefore, sEPS was a relatively small fraction of the total carbohydrate pool. sEPS formed, on average, $43 \pm 24 \%( \pm \mathrm{SD})$ of the saline-extractable fraction, which is consistent with Underwood et al. (1995) and Bellinger et al. (2005). Experiments with epipelic diatoms in culture have shown that EPS production is dependent both on environmental conditions (Underwood et al. 2004) and species (Goto et al. 1999). Although there were rapid changes in mudflat conditions during the emersion periods of Expts 1 and 2 (e.g. temperature), these did not affect changes in sEPS content. The simplest explanation for the linear relationship between the chl $a$ and sEPS content of the sediment (Fig. 5B) is that the MPB produced the sEPS.

The HW extract was a major pool of carbohydrate in the sediment, accounting for $18.6 \pm 9.2 \%$ of the total carbohydrate (mean $\pm \mathrm{SD}$ ). This extraction is composed of intracellular storage carbohydrates derived from diatoms in the form of $1 \rightarrow 3$ - $\beta$-D-glucan (chrysolaminaran) (Chiovitti et al. 2004, Bellinger et al. 2005), a conclusion supported by linkage analysis and the enrichment of HW extractions with glucose residues (Abdullahi et al. 2006). The high content of HW carbohydrates in the sediments of North Inlet suggests that glucose was a major component of the carbohydrate pool and that the intracellular storage products of diatoms comprise a significant proportion of the total carbohydrate. While only glucan has been identified as an intracellular storage carbohydrate in diatoms, monosaccharides other than glucose have been identified in HW extractions (Abdullahi et al. 2006, Hanlon et al. 2006). This indicates that HW extracts contain some extracellular carbohydrates, such as exopolymers associated with the cell walls of diatoms (Abdullahi et al. 2006). The significant positive correlation between the sediment content of chl $a$ and HW carbohydrates supports the hypothesis that the MPB were the major source of HW carbohydrates. Photosynthesis was not measured during this study, although it is well established that the MPB of North Inlet is photosynthetically active during daylight tidal emersion (Pinckney \& Zingmark 1993). Despite photosynthetic activity of the MPB during emersion, there was no accumulation of HW carbohydrates in the sediment, which would be expected if the MPB were storing a significant proportion of the carbon fixed. HB carbohydrates were $6.9 \pm$ $4.0 \%$ of the total carbohydrate and did not change significantly during Expts 1 and 2. The significant correlation between sediment chl a content and HB supports previous work that concluded that the HB fraction is composed of carbohydrates bound to the cell walls of diatoms (Bellinger et al. 2005, Abdullahi et al. 2006).

Measurement of significant wAPS content in the sediment indicates that the exopolymers contained acidic groups such as carboxyl $\left(-\mathrm{COO}^{-}\right)$and half-ester sulfates $\left(-\mathrm{OSO}_{3}{ }^{-}\right)$that stain with alcian blue (Passow \& Alldredge 1995, Thornton et al. 2007, Thornton \& Visser 2009). There was a significant correlation between the chl $a$ and the wAPS content of the sediment, which was also observed by Thornton \& Visser (2009) in samples from a subtropical salt marsh. wAPS content of the sediments in North Inlet ranged from 124 to $1563 \mu \mathrm{g} \mathrm{g}^{-1}$, compared to 0 to $793 \mu \mathrm{g} \mathrm{g}^{-1}$ at East Beach in Galveston Bay (Thornton \& Visser 2009). EPS produced by benthic diatoms is dominated by neutral sugars (Stal 2003, Underwood \& Paterson 2003), which do not bind with alcian blue. However, uronic acids (which contain carboxyl groups) are also produced by epipelic diatoms; Staats et al. (1999) found that the EPS bound to Cylindrotheca closterium was composed of both uronic acids and sulfated carbohydrates. Hanlon et al. (2006) measured uronic acids in the sediment during emersion and found that the HB fraction had a high uronic acid content, which agrees with Staats et al. (1999), as the HB fraction is regarded as relatively refractory cell-associated carbohydrate. Hanlon et al. (2006) also found uronic acids in the saline-extractable fraction ('colloidal carbohydrate' in their terminology). Uronic acids result in cross-linking between polymers, particularly in the presence of divalent cations (e.g. $\mathrm{Ca}^{2+}$ ), which form bonds between the $-\mathrm{COO}^{-}$groups. Cross-linking between polymer chains affects the structural properties of the polymers (Decho 1990, 2000, Van Boekel et al. 1992).

We expected that fractions of carbohydrate that are closely tied to photosynthesis, such as sEPS, sLMW, and HW, would increase during the daylight emersion 
period, as seen by Hanlon et al. (2006). Correlations between emersion time and the carbohydrate content of the sediment were not tested for Expt 1, as samples were only taken at 2 time points during the emersion period because the sediment was flooding at the third sampling point (Fig. 2A). However, sLMW did increase with emersion time in the surface sediment during Expt 2 and when the data were pooled for both Expts 1 and 2. The accumulation of sLMW may have been due to increased production, the observed accumulation of MPB biomass, or both. The correlation between emersion time and sLMW normalized to the chl a content of the sediment was not significant, indicating that increased sLMW in the sediment during tidal emersion was probably due to an increase in MPB biomass. Changes in the carbohydrate consumption rates will also determine whether carbohydrates accumulate in the sediment. Hancke \& Glud (2004) found that community respiration rates increased relative to photosynthesis with temperature in diatom dominated biofilms. Elevated glycosidase activity supports this hypothesis, as higher rates of exoenzyme activity indicate the production of more substrate to support respiration. We found that glycosidase activity and total enzyme activity increased with the increasing temperature during daylight emersion.

In addition to significant correlations between chl a and all carbohydrate fractions measured (Table 4), there were significant correlations between all carbohydrate fractions measured (Table 4). This suggests that there is coupling between the different carbohydrate fractions and supports the hypothesis that the carbohydrates produced at this site were dominated by MPB production, despite the dense stands of Spartina alterniflora that surrounded the sites. The wash-away of the MPB biomass in Expt 2 was not coupled to washaway of carbohydrate fractions in the sediment, which did not decrease in concentration after tidal immersion. Hanlon et al. (2006) found a significant decrease in saline-extractable and HW carbohydrates during tidal immersion, particularly during the first $30 \mathrm{~min}$ after tidal flooding. The insignificant decrease in carbohydrates observed in our experiments after tidal immersion may have resulted from the greater sediment depth sampled in our work, the patchiness of the habitat, not sampling later in the immersion period, or a combination of these factors.

\section{Relative exoenzyme activity}

Previous work on the activity of glycosidase enzymes in intertidal sediments has aimed to add saturating concentrations of the MUF-substrate. According to Michaelis-Menten enzyme kinetics, at saturating sub- strate concentrations the exoenzyme activity represents the maximum rate of enzyme activity $\left(V_{\max }\right)$. Measurements of enzyme activity at saturating substrate concentrations have been used as a measure of enzyme abundance in marine habitats (Nagata 2008). We used substrate concentrations of $100 \mu \mathrm{M}$, which although saturating in relatively cold and unproductive sites, such as deep sea sediments (Poremba \& Hoppe 1995), are unlikely to have been saturating in the sediments of North Inlet. Consequently, our rates do not represent 'enzyme activity' $\left(V_{\max }\right)$; they represent 'relative enzyme activity' with a substrate concentration of $100 \mu \mathrm{M}$. This means that the relative rates of the different enzymes can be compared within our study, but it is difficult to make direct comparisons to previous work in which $\beta$-glucosidase activities have been measured in intertidal sediments dominated by diatom biofilms (Van Duyl et al. 1999, Haynes et al. 2007). Haynes et al. (2007) used $1 \mathrm{mM}$ and Van Duyl et al. (1999) used 1 to $2 \mathrm{mM}$ final concentrations of 4 MUF- $\beta$-D-glucopyranoside to measure $\beta$-glucosidase activity. These substrate concentrations were assumed to be saturating in both studies and are an order of magnitude greater than the concentration we used. Boschker \& Cappenberg (1998) used saturating concentrations of $3.3 \mathrm{mM}$ to measure enzyme activity in the sediments of Lake Gooimeer in the Netherlands. Meyer-Reil (1986) found that $5 \mathrm{mM}$ substrate concentrations were insufficient to saturate enzyme activity in marine sediments from the Kiel Bight (Germany). King (1986) used a different approach, adding substrate analogs at concentrations of $<1 \mu \mathrm{M}$ to intertidal sediments and following the production of MUF over short incubation periods (<5 min). King's (1986) substrate addition was 2 orders of magnitude lower than ours.

While the enzyme substrate concentrations $(100 \mu \mathrm{M})$ used were unlikely to be saturating in the intertidal sediments of North Inlet, the measured rates of $\beta$-glucosidase activity were generally an order of magnitude higher than rates measured with $1 \mathrm{mM}$ substrate concentrations by Van Duyl et al. (1999) and Haynes et al. (2007). Haynes et al. (2007) measured $\beta$-glucosidase activity in a microcosm experiment using sediments from the Colne estuary (UK), and Van Duyl et al. (1999) measured $\beta$-glucosidase activity in sediments from the Ems-Dollard estuary. Environmental differences were probably a factor contributing to higher rates in North Inlet compared to northern Europe. Ecosystem temperature was maintained at $12^{\circ} \mathrm{C}$ in the microcosms of Haynes et al. (2007), while the emersed sediments of North Inlet were $\sim 20^{\circ} \mathrm{C}$ warmer. Temperature coefficients $\left(Q_{10}\right)$ from other sediment studies range from 2.3 to 3.5 times higher activity for every $10^{\circ} \mathrm{C}$ (Therkildsen \& Lomstein 1994). The $Q_{10}$ in part could account for the order of magnitude higher level of enzymatic activity 
we observed. Differences in the methods for the enzyme assays will also affect the results. For example, high concentrations of substrate are known to cause substrate inhibition of $\beta$-glucosidase (Yagüe \& Estévez 1988, Woodward \& Clarke 1991). The saturating substrate concentration may be determined by measuring exoenzyme rates at a range of substrate concentrations and fitting a Michaelis-Menten equation to the data.

There was significant hydrolysis of all the enzyme substrate analogs added to the sediment, indicating that polysaccharide hydrolysis was affected by $\beta$-glucosidase, $\alpha$-glucosidase, $\beta$-galactosidase, $\alpha$-galactosidase, and $\beta$-xylosidase. It should be noted that each of these exoenzymes represents a broad type; for example, the sediments of North Inlet probably contained many $\beta$-glucosidases, differing in physical, functional, and genetic characteristics (Nagata 2008). The relative activity of the exoenzymes followed this sequence in the sediment: $\beta$-glucosidase $>\alpha$-glucosidase $>(\beta$ xylosidase $=\beta$-galactosidase $=\alpha$-galactosidase $)$. Exoenzyme activity is indicative of the availability of substrates and consequently the composition of polymeric organic matter in the sediment (Boschker \& Cappenberg 1998). Therefore, the sediments of North Inlet contained polysaccharides that contained glucose, xylose, and galactose. Furthermore, the glucose and galactose were both $\beta$ and $\alpha$-linked to surrounding monomers in the polymers.

To our knowledge, these data represent the first measurement of glycosides, other than $\beta$-glucosidase, in intertidal sediments dominated by MPB. King (1986) measured the relative activity of several $\beta$-glycosidases (glucosidase, galactosidase, mannosidase, xylosidase, glucouronidase, arabinosidase, fucosidase) and found measurable rates of activity for all exoenzymes. However, he did not relate exoenzyme activity to either sediment carbohydrates or the biomass of the MPB. King (1986) measured exoenzyme activity in the surface 0 to $2 \mathrm{~cm}$ of the sediment, which is deeper than the layer inhabited by the MPB. King (1986) did not measure the activity of either $\alpha$-glucosidase or $\alpha$-galactosidase, which made a significant contribution to the total relative exoenzyme activity in our study.

It is not surprising that relative rates of $\beta$-glucosidase were high, as this enzyme is involved in the hydrolysis of cellulose (Boetius \& Lochte 1994) and the glucan storage product found in diatoms, which is a polymer of $\beta$-1 $\rightarrow 3$-linked glucose monomers (Chiovitti et al. 2004, Bellinger et al. 2005). $\alpha$-glucosidase is involved in the breakdown of starch, a plant storage product (Robyt 1998, Sinnott 2007). We observed a significant positive correlation between relative $\alpha$-glucosidase activity and the HW carbohydrate content of the sediment, which may indicate that this fraction contains $\alpha$ linked glucose in addition to glucan. The bare sedi- ments of Expts 1 and 2 were surrounded by beds of Spartina alterniflora, which were a potential source of these carbohydrates in addition to the MPB. Glucose is the major constituent of the vast majority of carbohydrates on Earth (Robyt 1998). Glucose probably dominated the carbohydrates of North Inlet, as there was a positive correlation between total carbohydrate and the relative rates of $\alpha$-glucosidase. Hofmann et al. (2009) found that the proportion of glucose in sediment carbohydrates decreased over time during slurry experiments, which they interpreted as a preference by intertidal sediment bacteria for glucose over other monosaccharides. Our data support this observation, as glucosidases made up $70 \%$ of the total relative exoenzyme activity, indicating either an abundance of glucose in the sediment carbohydrates, a preference for glucose over other monosaccharides, or a combination of both.

Xylose and galactose are components of hemicelluloses, which consist of $\beta-1 \rightarrow 4$ linked heteropolysaccharides and are a major component of plant cell walls (Robyt 1998, Sinnott 2007). Xylose is also a component of diatom cell walls (Staats et al. 1999). Therefore, $\beta$ xylosidase and $\beta$-galactosidase activity may have affected the hydrolysis of cell wall components from both MPB and plant fragments in the sediment. Previous work has shown that EPS produced by benthic diatoms is dominated by neutral sugars such as glucose, mannose, galactose, glucose, xylose, and rhamnose (Stal 2003, Underwood \& Paterson 2003). Therefore, it is likely that all glycosidic enzymes investigated affected the hydrolysis of saline-extractable carbohydrates and EPS produced by the MPB biofilm.

\section{CONCLUSIONS}

All carbohydrate fractions were positively correlated with MPB biomass and one another, which indicates that the MPB was the major source of carbohydrates in the sediment. During Expt 2, MPB biomass accumulated in the surface $5 \mathrm{~mm}$ over the course of the emersion period, and there was a substantial reduction in MPB biomass after tidal flooding of the sediment (50 \pm $21 \%$; mean $\pm \mathrm{SD}, \mathrm{n}=5$ ). These results confirm those of Hanlon et al. (2006), who showed that MPB biomass accumulates at the sediment surface during tidal emersion and that a significant proportion of this biomass is washed away by the incoming tide on immersion.

While no specific relationships between $\beta$-glycosidases and any of the carbohydrate fractions were identified, the relative activity of $\alpha$-glucosidase positively correlated with the total and HW fractions, and the relative activity of $\alpha$-galactosidase positively correlated with the saline-extractable and sLMW fractions. These 
relationships indicate that these enzymes play a role in the hydrolysis of these specific fractions.

$H_{1}$ was supported, as the mean relative exoenzyme activity of each enzyme measured was significantly $>0$, indicating that $\beta$-glucosidase, $\alpha$-glucosidase, $\beta$ galactosidase, $\alpha$-galactosidase, and $\beta$-xylosidase all play a significant role in the hydrolysis of oligo- and polysaccharides within the MPB-dominated intertidal sediments of North Inlet. Glucosidase enzymes dominated the hydrolysis of carbohydrates within the sediment, contributing $70 \pm 6 \%$ (mean $\pm \mathrm{SD}$ ) of the total enzyme activity. It is highly likely that exoenzymes that were not included in this study were also significant in the hydrolysis of carbohydrates within the sediment. For example, the ubiquitous presence of APS within the sediment suggests that glucouronidase may have played a significant role in the degradation of sediment carbohydrates. The balance of production and hydrolysis of sediment APS will play an important role in determining the high concentrations of dissolved APS in the water column of North Inlet, which are hypothesized to be introduced to the water column via wash-away (Thornton 2009). $H_{2}$ was supported for total relative exoenzyme activity, which changed over the course of the emersion period, with the lowest rates of total relative exoenzyme activity occurring immediately after tidal emersion. $H_{3}$ was rejected, as none of the exoenzymes measured significantly correlated with the sEPS content of the sediment. This may be because sEPS was a relatively small proportion of the total carbohydrate within the sediment (Fig. 4) and therefore other complex pools of carbohydrate were more important in affecting enzyme activity in addition to physical factors such as temperature. $H_{4}$ was rejected as there was no evidence that increasing availability of sLMW in the sediment had the effect of inhibiting glycosidase activity; none of the glycosidases measured showed a significant negative correlation between relative activity and the sLMW content of the sediment.

Acknowledgements. We thank S. C. Neubauer and P. Kenny for their advice and support during fieldwork at the BMFL. Additional monitoring data from Oyster Landing was downloaded from the CDMO, BMFL, University of South Carolina (USC $;$ http://cdmo.baruch.sc.edu). Monitoring at Oyster Landing in North Inlet-Winyah Bay was conducted under an award for the Estuarine Reserves Division, Office of Ocean and Coastal Resource Management, National Ocean Service, National Oceanic and Atmospheric Administration. D.C.O.T. was supported by a Visiting Scientist award from the Belle W. Baruch Institute for Marine and Coastal Sciences to conduct research at the BMFL. S.M.K. was supported by a National Science Foundation REU award DBI-0451403 to B. Ely at USC. R.A.L. was supported by start-up funds from USC. We thank 2 anonymous reviewers whose advice significantly improved the final manuscript.

\section{LITERATURE CITED}

Abdullahi AS, Underwood GJC, Gretz MR (2006) Extracellular matrix assembly in diatoms (Bacillariophyceae). V. Environmental effects on polysaccharide synthesis in the model diatom, Phaeodactylum tricornutum. J Phycol 42: 363-378

Arnosti C (2004) Speed bumps and barricades in the carbon cycle: substrate structural effects on carbon cycling. Mar Chem 92:263-273

> Bellinger BJ, Abdullahi AS, Gretz MR, Underwood GJC (2005) Biofilm polymers: relationship between carbohydrate biopolymers from estuarine mudflats and unialgal cultures of benthic diatoms. Aquat Microb Ecol 38: 169-180

> Bellinger BJ, Underwood GJC, Ziegler SE, Gretz MR (2009) Significance of diatom-derived polymers in carbon flow dynamics within estuarine biofilms determined through isotopic enrichment. Aquat Microb Ecol 55:169-187

Bianchi TS (2007) Biogeochemistry of estuaries. Oxford University Press, New York, NY

Blanchard GF, Guarini JM, Richard P, Gros Ph, Mornet F (1996) Quantifying the short-term temperature effect on light-saturated photosynthesis of intertidal microphytobenthos. Mar Ecol Prog Ser 134:309-313

Boetius A, Lochte K (1994) Regulation of microbial enzymatic degradation of organic matter in deep-sea sediments. Mar Ecol Prog Ser 104:299-307

Boschker HTS, Cappenberg TE (1998) Patterns of extracellular enzyme activities in littoral sediments of Lake Gooimeer, The Netherlands. FEMS Microbiol Ecol 25: 79-86

Brotas V, Mendes CR, Cartaxana P (2007) Microphytobenthic biomass assessment by pigment analysis: comparison of spectrophotometry and high performance liquid chromatography methods. Hydrobiologia 587:19-24

Chiovitti A, Molino P, Crawford SA, Teng RW, Spurck T, Wetherbee R (2004) The glucans extracted with warm water from diatoms are mainly derived from intracellular chrysolaminaran and not extracellular polysaccharides. Eur J Phycol 39:117-128

de Brouwer JFC, Stal LJ (2001) Short-term dynamics in microphytobenthos distribution and associated extracellular carbohydrates in surface sediments of an intertidal mudflat. Mar Ecol Prog Ser 218:33-44

de Brouwer JFC, Wolfstein K, Stal LJ (2002) Physical characterization and diel dynamics of different fractions of extracellular polysaccharides in an axenic culture of a benthic diatom. Eur J Phycol 37:37-44

$>$ De Jonge VN, Colijn F (1994) Dynamics of microphytobenthos biomass in the Ems estuary. Mar Ecol Prog Ser 104: 185-196

> De Jonge VN, Van Beusekom JEE (1992) Contribution of resuspended microphytobenthos to total phytoplankton in the Ems estuary and its possible role for grazers. Neth J Sea Res 30:91-105

Decho AW (1990) Microbial exopolymer secretions in ocean environments - their role(s) in food webs and marine processes. Oceanogr Mar Biol Annu Rev 28:73-153

Decho AW (2000) Microbial biofilms in intertidal systems: an overview. Cont Shelf Res 20:1257-1273

> Dubois M, Gilles KA, Hamilton JK, Rebers PA, Smith F (1956) Colorimetric method for determination of sugars and related substances. Anal Chem 28:350-356

Falkowski P, Scholes RJ, Boyle E, Canadell J and others (2000) The global carbon cycle: a test of our knowledge of earth as a system. Science 290:291-296 
Glud RN, Kühl M, Wenzhöfer F, Rysgaard S (2002) Benthic diatoms of a high Arctic fjord (Young Sound, NE Greenland): importance for ecosystem primary production. Mar Ecol Prog Ser 238:15-29

Goto N, Kawamura T, Mitamura O, Terai H (1999) Importance of extracellular organic carbon production in the total primary production by tidal-flat diatoms in comparison to phytoplankton. Mar Ecol Prog Ser 190:289-295

Guarini JM, Gros P, Blanchard G, Richard P, Fillon A (2004) Benthic contribution to pelagic microalgal communities in two semi-enclosed, European-type littoral ecosystems (Marennes-Oleron Bay and Aiguillon Bay, France). J Sea Res 52:241-258

- Hancke K, Glud RN (2004) Temperature effects on respiration and photosynthesis in three diatom-dominated benthic communities. Aquat Microb Ecol 37:265-281

Hanlon ARM, Bellinger B, Haynes $\mathrm{K}$, Xiao $\mathrm{G}$ and others (2006) Dynamics of extracellular polymeric substance (EPS) production and loss in an estuarine, diatom-dominated, microalgal biofilm over a tidal emersion-immersion period. Limnol Oceanogr 51:79-93

- Haynes K, Hofmann TA, Smith CJ, Ball AS, Underwood GJC, Osborn AM (2007) Diatom-derived carbohydrates as factors affecting bacterial community composition in estuarine sediments. Appl Environ Microbiol 73:6112-6124

Hofmann T, Hanlon ARM, Taylor JD, Ball AS, Osborn AM, Underwood GJC (2009) Dynamics and compositional changes in extracellular carbohydrates in estuarine sediments during degradation. Mar Ecol Prog Ser 379:45-58

- Holland AF, Zingmark RG, Dean JM (1974) Quantitative evidence concerning stabilization of sediments by marine benthic diatoms. Mar Biol 27:191-196

Hoppe HG (1983) Significance of exoenzymatic activities in the ecology of brackish water: measurements by means of methylumbelliferyl substrates. Mar Ecol Prog Ser 11: 299-308

> Hung CC, Guo LD, Santschi PH, Alvarado-Quiroz N, Haye JM (2003) Distributions of carbohydrate species in the Gulf of Mexico. Mar Chem 81:119-135

King GM (1986) Characterization of $\beta$-glucosidase activity in intertidal marine sediments. Appl Environ Microbiol 51: $373-380$

Meyer-Reil LA (1986) Measurement of hydrolytic activity and incorporation of dissolved organic substrates by microorganisms in marine sediments. Mar Ecol Prog Ser 31: 143-149

Middelburg JJ, Barranguet C, Boschker HTS, Herman PMJ, Moens T, Heip CHR (2000) The fate of intertidal microphytobenthos carbon: an in situ ${ }^{13} \mathrm{C}$-labeling study. Limnol Oceanogr 45:1224-1234

Morris EP, Kromkamp JC (2003) Influence of temperature on the relationship between oxygen- and fluorescence-based estimates of photosynthetic parameters in a marine benthic diatom (Cylindrotheca closterium). Eur J Phycol 38: $133-142$

Nagata T (2008) Organic matter-bacteria interactions in seawater. In: Kirchman DL (ed) Microbial ecology of the oceans. 2nd edn. Wiley-Blackwell, Hoboken, NJ

Passow U, Alldredge AL (1995) A dye-binding assay for the spectrophotometric measurement of transparent exopolymer particles (TEP). Limnol Oceanogr 40:1326-1335

- Perkins RG, Honeywill C, Consalvey M, Austin HA, Tolhurst TJ, Paterson DM (2003) Changes in microphytobenthic chlorophyll $a$ and EPS resulting from sediment compaction due to de-watering: opposing patterns in concentration and content. Cont Shelf Res 23:575-586

Pinckney JL, Zingmark RG (1993) Modeling the annual pro- duction of intertidal benthic microalgae in estuarine ecosystems. J Phycol 29:396-407

Poremba K, Hoppe HG (1995) Spatial variation of benthic microbial production and hydrolytic enzyme activity down the continental slope of the Celtic Sea. Mar Ecol Prog Ser 118:237-245

Ramus J (1977) Alcian blue: a quantitative aqueous assay for algal acid and sulfated polysaccharides. J Phycol 13: 345-348

Robyt JF (1998) Essentials of carbohydrate chemistry. Springer-Verlag, New York, NY

Santos PJP, Castel J, Souza-Santos LP (1997) Spatial distribution and dynamics of microphytobenthos biomass in the Gironde estuary (France). Oceanol Acta 20:549-556

Santschi PH, Hung CC, Schultz G, Alfarado-Quiroz N, Guo LD, Pinckney J, Walsh I (2003) Control of acid polysaccharide production and ${ }^{234} \mathrm{Th}$ and $\mathrm{POC}$ export fluxes by marine organisms. Geophys Res Lett 30,1044, doi: 10.1029/2002GL016046

Sêrodio J, da Silva JM, Catarino F (1997) Nondestructive tracing of migratory rhythms of intertidal benthic microalgae using in vivo chlorophyll a fluorescence. J Phycol 33: $542-553$

Sinnott ML (2007) Carbohydrate chemistry and biochemistry. The Royal Society for Chemistry, Cambridge

Smith DJ, Underwood GJC (1998) Exopolymer production by intertidal epipelic diatoms. Limnol Oceanogr 43: 1578-1591

- Staats N, De Winder B, Stal LJ, Mur LR (1999) Isolation and characterization of extracellular polysaccharides from the epipelic diatoms Cylindrotheca closterium and Navicula salinarum. Eur J Phycol 34:161-169

Staats N, Stal LJ, de Winder B, Mur LR (2000) Oxygenic photosynthesis as driving process in exopolysaccharide production of benthic diatoms. Mar Ecol Prog Ser 193: 261-269

Stal LJ (2003) Microphytobenthos, their extracellular polymeric substances, and the morphogenesis of intertidal sediments. Geomicrobiol J 20:463-478

Stal LJ, Vangemerden H, Krumbein WE (1984) The simultaneous assay of chlorophyll and bacteriochlorophyll in natural microbial communities. J Microbiol Methods 2: 295-306

Takai N, Yorozu A, Tanimoto T, Hoshika A, Yoshihara K (2004) Transport pathways of microphytobenthos-originating organic carbon in the food web of an exposed hard bottom shore in the Seto Inland Sea, Japan. Mar Ecol Prog Ser 284:97-108

Therkildsen MS, Lomstein BA (1994) Seasonal variation in sediment urea turnover in a shallow estuary. Mar Ecol Prog Ser 109:77-82

Thornton DCO (2009) Spatiotemporal distribution of dissolved acidic polysaccharides (dAPS) in a tidal estuary. Limnol Oceanogr 54:1449-1460

Thornton DCO, Visser LA (2009) Measurement of acid polysaccharides (APS) associated with microphytobenthos in salt marsh sediments. Aquat Microb Ecol 54:185-198

- Thornton DCO, Dong LF, Underwood GJC, Nedwell DB (2002) Factors affecting microphytobenthic biomass, species composition and production in the Colne Estuary (UK). Aquat Microb Ecol 27:285-300

Thornton DCO, Fejes EM, DiMarco SF, Clancy KM (2007) Measurement of acid polysaccharides in marine and freshwater samples using alcian blue. Limnol Oceanogr Methods 5:73-87

> Tolhurst TJ, Defew EC, de Brouwer JFC, Wolfstein K, Stal LJ, Paterson DM (2006) Small-scale temporal and spatial vari- 
ability in the erosion threshold and properties of cohesive intertidal sediments. Cont Shelf Res 26:351-362

Underwood AJ (1997) Experiments in ecology. Cambridge University Press, Cambridge

Underwood GJC, Kromkamp J (1999) Primary production by phytoplankton and microphytobenthos in estuaries. Adv Ecol Res 29:93-153

Underwood GJC, Paterson DM (2003) The importance of extracellular carbohydrate production by marine epipelic diatoms. Adv Bot Res 40:183-240

Underwood GJC, Paterson DM, Parkes RJ (1995) The measurement of microbial carbohydrate exopolymers from intertidal sediments. Limnol Oceanogr 40:1243-1253

Underwood GJC, Boulcott M, Raines CA, Waldron K (2004) Environmental effects on exopolymer production by marine benthic diatoms: dynamics, changes in composition, and pathways of production. J Phycol 40:293-304

> Van Boekel WHM, Hansen FC, Riegman R, Bak RPM (1992) Lysis-induced decline of a Phaeocystis spring bloom and coupling with the microbial foodweb. Mar Ecol Prog Ser 81:269-276

Van Duyl FC, de Winder B, Kop AJ, Wollenzien U (1999) Tidal

Editorial responsibility: Rudger de Wit, Montpellier, France coupling between carbohydrate concentrations and bacterial activities in diatom-inhabited intertidal mudflats. Mar Ecol Prog Ser 191:19-32

> Verdugo P, Alldredge AL, Azam F, Kirchman DL, Passow U, Santschi PH (2004) The oceanic gel phase: a bridge in the DOM-POM continuum. Mar Chem 92:67-85

- Weiss MS, Abele U, Weckesser J, Welte W, Schiltz E, Schulz GE (1991) Molecular architecture and electrostatic properties of a bacterial porin. Science 254:1627-1630

Werner U, Blazejak A, Bird P, Eickert G and others (2008) Microbial photosynthesis in coral reef sediments (Heron Reef, Australia). Estuar Coast Shelf Sci 76:876-888

> Wolfstein K, Stal LJ (2002) Production of extracellular polymeric substances (EPS) by benthic diatoms: effect of irradiance and temperature. Mar Ecol Prog Ser 236: $13-22$

Woodward J, Clarke KM (1991) Hydrolysis of cellobiose by immobilized $\beta$-glucosidase entrapped in maintenance free gel spheres. Appl Biochem Biotechnol 28/29:277-283

Yagüe E, Estévez MP (1988) Purification and characterization of a $\beta$-glucosidase from Evernia prunastri. Eur J Biochem $175: 627-632$

Submitted: April 7, 2009; Accepted: January 14, 2010 Proofs received from author(s): May 4, 2010 